FACULDADE DE TECNOLOGIA E CIÊNCIAS SOCIAIS APLICADASFATECS

PROGRAMA DE INICIAÇÃO CIENTÍFICA

FERNANDA LOPES OLIVEIRA

MELHORAMENTO DE SOLOS ATRAVÉS DA INCORPORAÇÃO DE FIBRAS RECICLADAS:

FIBRA CERÂMICA E FIBRA PROMEX

BRASÍLIA

2017 


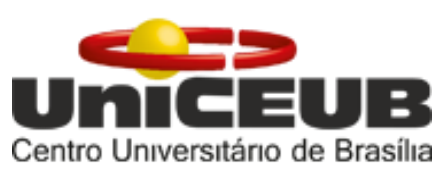

FERNANDA LOPES OLIVEIRA

\section{MELHORAMENTO DE SOLOS ATRAVÉS DA INCORPORAÇÃO DE FIBRAS RECICLADAS: \\ FIBRA CERÂMICA E FIBRA PROMEX} Relatório final de pesquisa de Iniciação Científica
apresentado à Assessoria de Pós-Graduação e
Pesquisa pela Faculdade de Tecnologia e
Ciências Sociais Aplicadas - FATECS.

Orientação: Ivonne Alejandra Maria Gutiérrez Góngora, Ph.D

BRASÍLIA 


\title{
2017 \\ MELHORAMENTO DE SOLOS ATRAVÉS DA INCORPORAÇÃO DE FIBRAS RECICLADAS : \\ FIBRA CERÂMICA E FIBRA PROMEX
}

\author{
Fernanda Lopes Oliveira - UniCEUB, PIC Institucional, aluno bolsista \\ Lopesfernanda411@gmail.com
}

Ivonne Alejandra Maria Gutiérrez Góngora - UniCEUB, professor orientador

\author{
Jaime Rafael Obando Ante - Universidad del Cauca, professor colaborador \\ jaimeobando@unicauca.edu.co
}

Por se tratar de um país ainda em desenvolvimento, o Brasil possui um grande parque siderúrgico, responsável por grande parte do seu PIB, no ano de 2014 a produção mineira atingiu o valor de US\$ 40 bilhões, o que representou cerca de $5 \%$ do PIB Industrial do país. Outro setor primário de relevância para a economia Brasileira é o das indústrias têxteis, que ano a ano expandem suas atividades consideravelmente no território nacional. Os dois setores supracitados geram dentro dos seus processos industriais uma grande quantidade de resíduos de fibra têxtil e fibras cerâmicas, que na maioria das vezes não são reciclados ou descartados apropriadamente, gerando consideráveis problemas ambientais. Como alternativa para dar um uso apropriado às fibras descartadas, é proposta na presente pesquisa uma metodologia para o aproveitamento das fibras recicladas cerâmicas e têxtil, denominada de fibra PROMEX, no melhoramento de solos lateríticos, procurando dar aplicações ao compósito na engenharia geotécnica. Para efeitos de comparação foram misturadas fibras ao solo laterítico de Brasília em proporção de 0,5\% com relação à massa seca do solo, e comparando o efeito com um solo no estado natural. Na avaliação das mudanças nas propriedades mecânicas foram compactados corpos de prova cilíndricos através da metodologia mini-MCV de $50 \mathrm{~mm}$ de diâmetro, avaliando resistência à tração, resistência à compressão e da resistência ao cisalhamento em corpos de prova compactados segundo a metodologia Proctor. Dentro das principais conclusões da pesquisa foi possível estabelecer que a incorporação de fibras cerâmicas melhoram consideravelmente o comportamento mecânico do solo para tração e compressão, já a fibra PROMEX obteve melhor resultado pra ensaio de resistência ao cisalhamento.

Palavras-Chave: melhoramento de solos, solos lateríticos, fibras recicladas, sustentabilidade. 


\begin{abstract}
As it is a developing country, Brazil has a large steelmaking industry, responsible for a large part of its GDP, in 2014, the mining production reached US \$ 40 billion, which represented around 5\% of the country's Industrial GDP. Another relevant primary sector to the Brazilian economy is the textile industries, which year after year expand their activities considerably in the national territory. The two sectors mentioned above generate in their industrial processes a large amount of waste of textile fiber and ceramic fibers, which in most cases are not recycled or disposed properly, generating considerable environmental problems. As an alternative to give an appropriate use to discarded fibers, a methodology is proposed in the present research for the use of recycled ceramic fibers and textile, called PROMEX fibers, in the improvement of lateritic soils, seeking to give applications to the composite in geotechnical engineering. For comparison purposes, fibers were mixed to the lateritic soil of Brasília in a proportion of $0.5 \%$ in relation to the dry mass of the soil, and comparing the effect with a soil in its natural state. In the evaluation of the mechanical properties changes, cylindrical specimens were compacted through the mini-MCV methodology of $50 \mathrm{~mm}$ in diameter, evaluating tensile strength, compressive strength and shear strength in compacted specimens according to the Proctor methodology. Within the main conclusions of the research it was possible to establish that the incorporation of ceramic fibers considerably improves the mechanical performance of the soil, and the PROMEX fiber obtained better results for the shear strength test.
\end{abstract}

key-words: improvement of soils, lateritic soils, recycled fibers, sustainability. 


\section{Sumário}

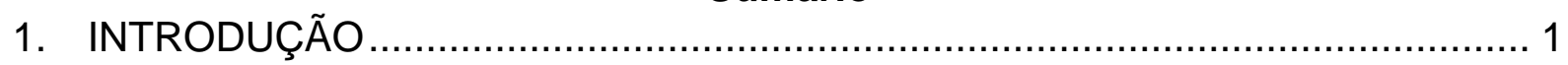

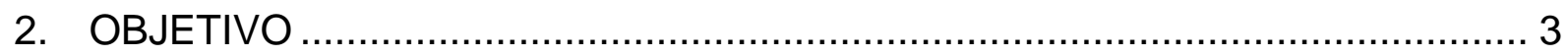

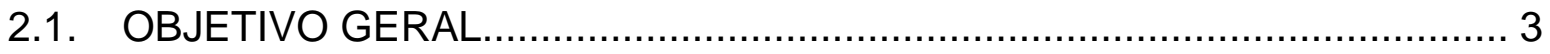

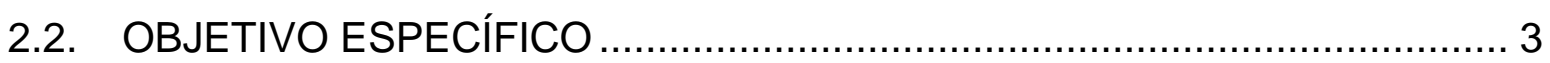

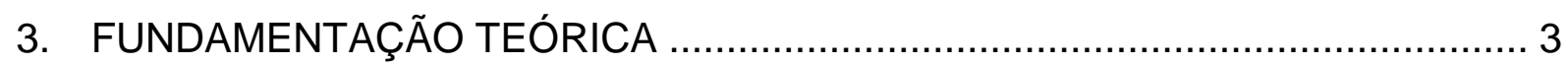

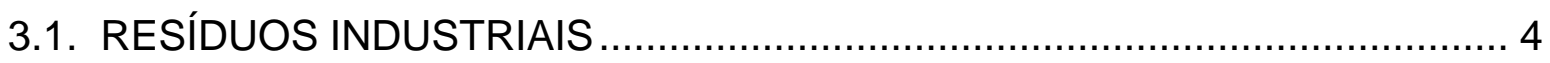

3.1.1 Resíduos siderúrgicos e metalúrgicos ................................................. 4

3.1.2 Resíduos de indústrias de maquinas e equipamentos .............................. 5

3.1.3 Resíduos de indústrias têxteis ......................................................... 5

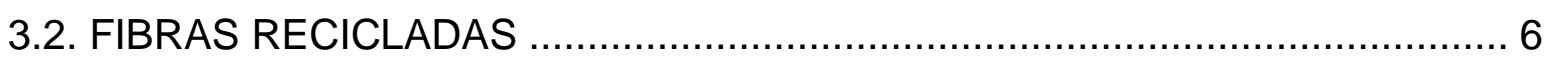

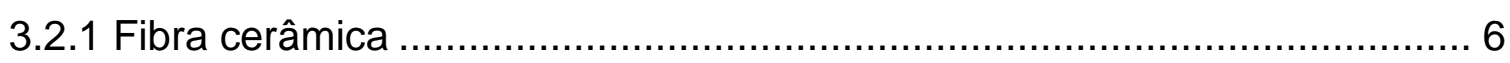

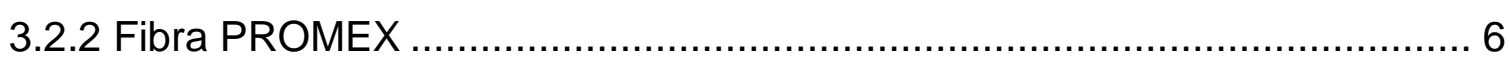

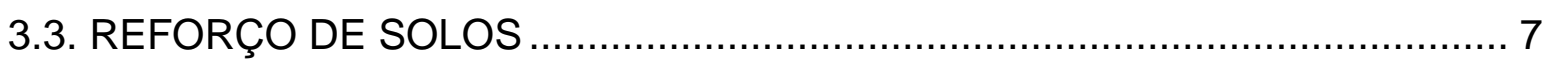

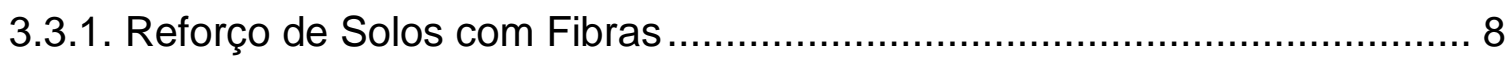

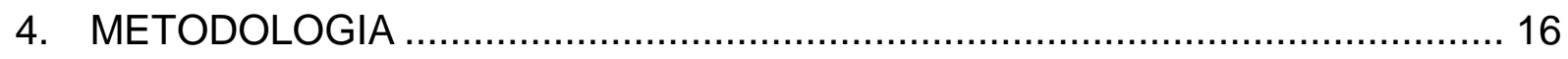

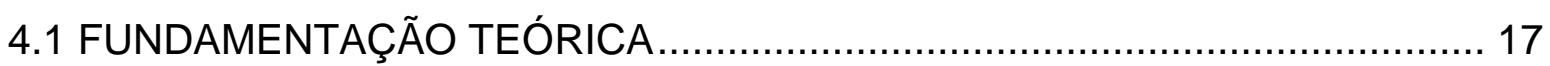

4.2 SELEÇÃO E COLETA DOS MATERIAIS ................................................ 17

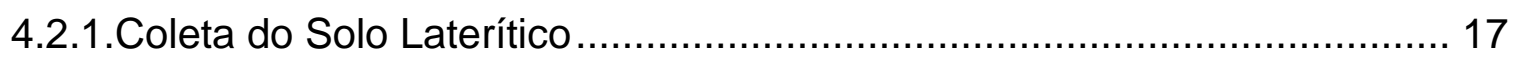

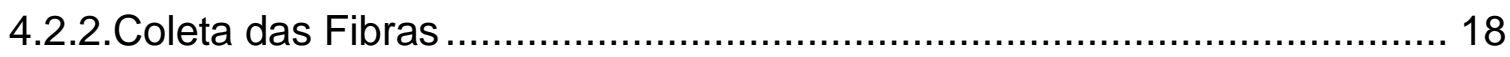

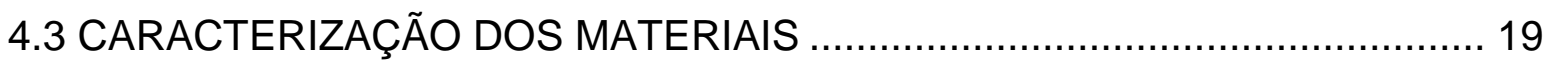

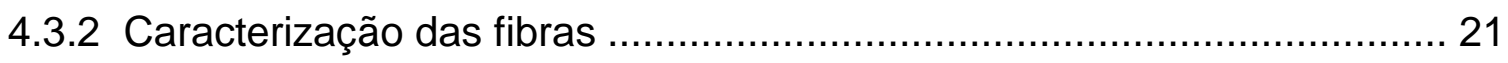

4.4 DETERMINAÇÃO DO TEOR ÓTIMO DE FIBRA ....................................... 23

4.5 DETERMINAÇÃO DAS CONDIÇÕES DE COMPACTAÇÃO DOS CORPOS

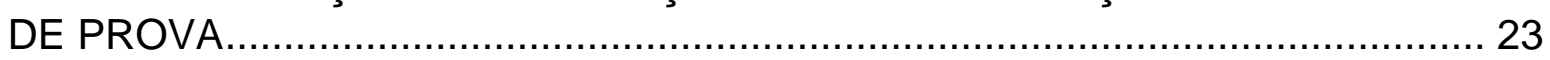

4.6 ELABORAÇÃO DOS CORPOS DE PROVA .............................................. 24

4.7 DETERMINAÇÃO DA RESISTÊNCIA À COMPRESSÃO E A TRAÇÃO ........ 29

4.8 DETERMINAÇÃO DA RESISTÊNCIA AO CISALHAMENTO DIRETO ............ 30

4.9 ANÁLISE E COMPARAÇÃO DOS RESULTADOS ....................................... 31

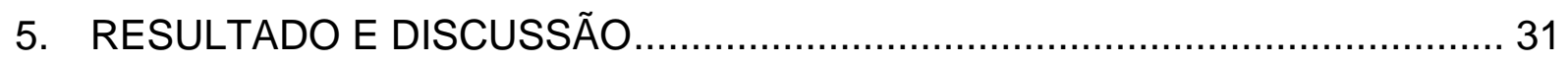

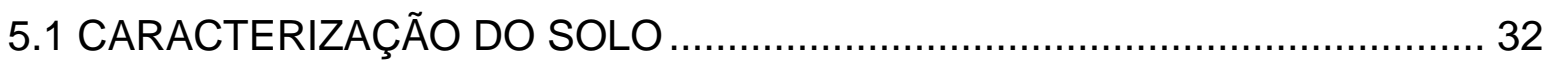

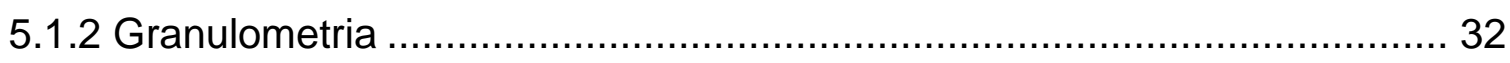

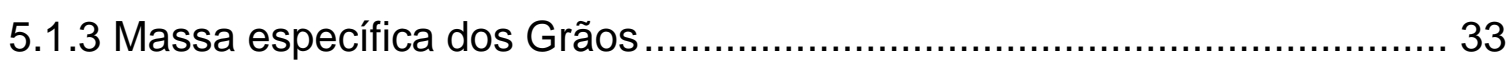

5.1.4 Metodologia MCT expedita ......................................................... 33 
5.1.5 Limites de Atteberg …………...................................................... 33

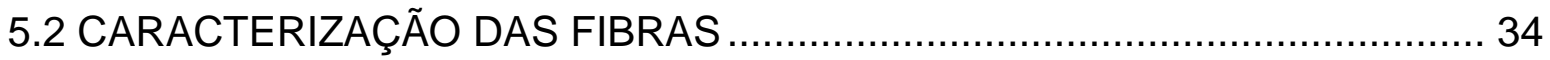

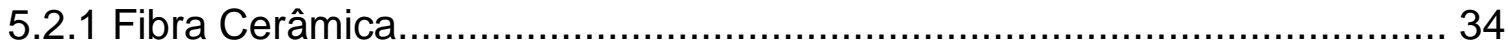

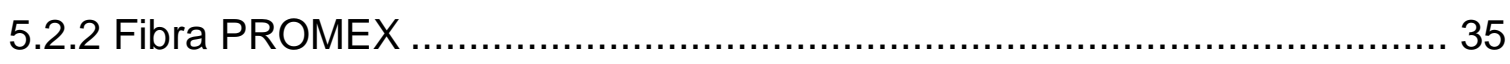

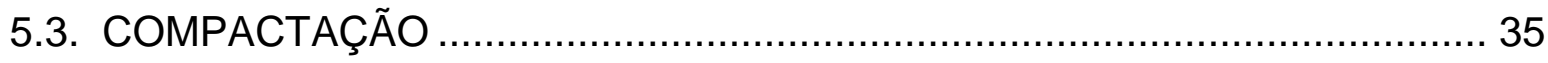

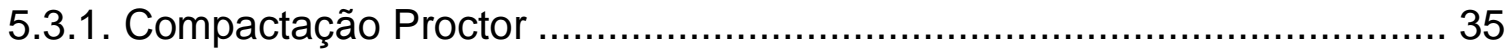

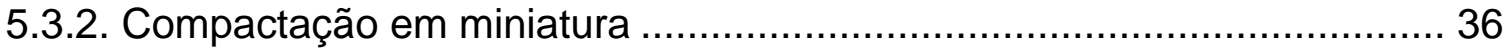

5.4 ENSAIO DE RESISTÊNCIA MECÂNICA À COMPRESSÃO E A TRAÇÃO ... 37

5.5. ENSAIO DE RESISTÊNCIA MECÂNICA AO CISALHAMENTO DIRETO ..... 43

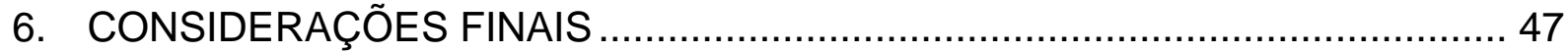

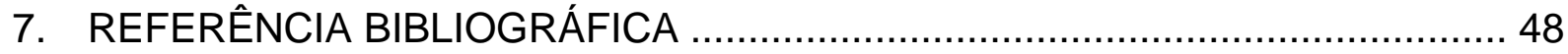




\section{Lista de Figuras}

Figura 3.1 Métodos de reforço de solos. (DIAS, 2013)......................................... 7

Figura 3.2Mecanismo para retardar as fissuras (Ferrante apud Sales ,2011)........... 9

Figura 3.3 Resultado do ensaio de cisalhamento direto: (a) $50 \mathrm{KPa}$ (b) $100 \mathrm{KPa}$ (c)

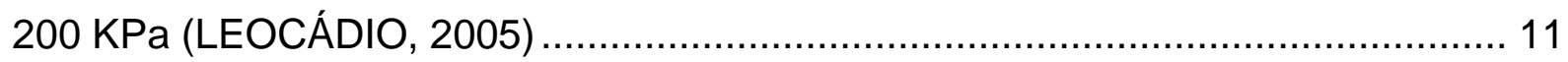

Figura 3.4 Envoltório de ruptura (LEOCÁDIO, 2005) .............................................. 12

Figura 3.5 Deformação axial (CASAGRANDE, 2005) .......................................... 13

Figura 3.6 Curva de Ruptura (CASAGRANDE,2005) ...................................... 14

Figura 3.7 Ensaios realizados para verificar a resistência: (a) a compressão (b) ao triaxial sem reforço (c) ao triaxial com reforço (TRINDADE ,2006) ........................ 15

Figura 4.1 Localização da coleta de solo ..................................................... 18

Figura 4.2 Local de retirada do solo utilizado ....................................................... 18

Figura 4.3 Fibra utilizadas (a) fibra cerâmica (b) fibra PROMEX............................ 19

Figura 4.4 Etapas do ensaio de granulometria (a) Peneiramento do material grosso

(b) Sedimentação da parte fina .................................................................. 20

Figura 4.5 Ensaio de Massa Específica …………....................................... 20

Figura 4.6 Equipamento de Casa Grande para determinar limite de liquidez ......... 20

Figura 4.7 Determinação do limite de plasticidade ............................................. 21

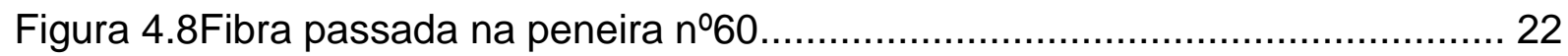

Figura 4.9 Equipamento pentapicnômetro ...................................................... 22

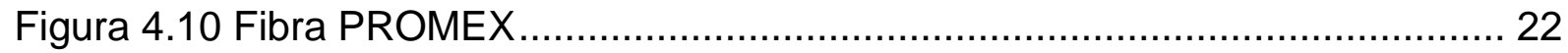

Figura 4.11 Tentativa de imersão em água da fibra ......................................... 23

Figura 4.12 Fibras aleatoriamente distribuídas no solo : (a) fibra cerâmica; (b) fibra

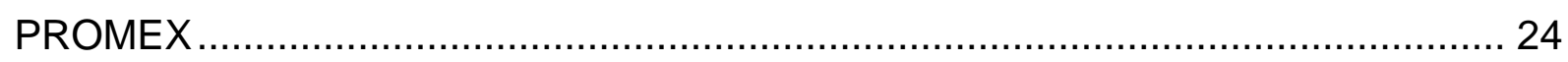

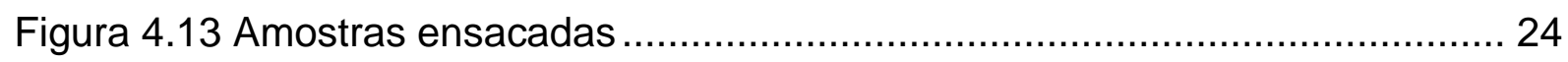

Figura 4.14 Adaptação da fibra PROMEX ao solo (a) sem adição de água (b) com

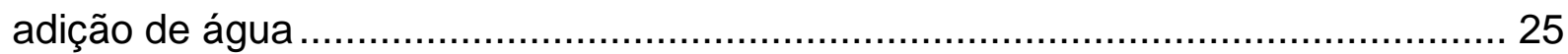

Figura 4.15 Equipamento para compactação (a) materiais para compactação (b)

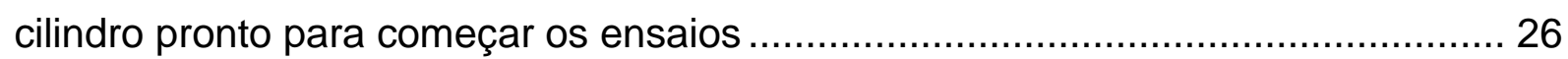

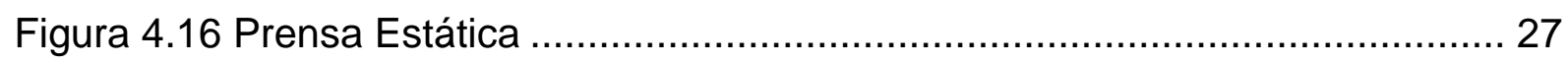

Figura 4.17 Corpos de prova compactados (a) corpo e prova para ensaio de compressão simples (b) corpo e prova para ensaio resistência a tração...... 28 
Figura 4.18 Embalagem dos corpos de prova (a) embalado em papel filme (b) embalado em papel alumínio (c) caixa térmica para armazenamento 28

Figura 4.19 Medidas dos corpos de prova ……….......................................... 29

Figura 4.20 Máquina utilizada para rompimento dos corpos de prova .................... 30

Figura 4.21 Determinação da resistência à tração ………….............................. 30

Figura 4.22 Máquina de cisalhamento direto................................................... 31

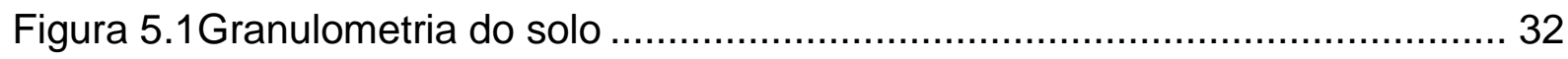

Figura 5.2 Curva de Limite de Liquidez ........................................................ 34

Figura 5.3 Curvas de compactação ............................................................ 36

Figura 5.4 Curvas de Resistência à Compressão Simples...................................... 38

Figura 5.5 Fissuras no solo : (a) Solo Natural (b)Solo com Fibra PROMEX (c) Solo

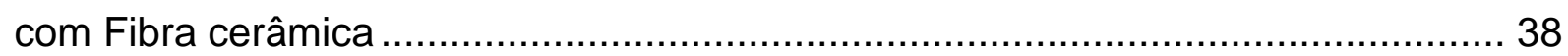

Figura 5.6 Deformação do Solo Natural ........................................................ 39

Figura 5.7 Deformação do Solo + Fibra PROMEX ………................................ 39

Figura 5.8 Deformação do Solo + Fibra Cerâmica ................................................. 40

Figura 5.9 Curvas de Resistência à Tração................................................... 41

Figura 5.10 Deformação do Solo Natural para esforço de tração.............................. 41

Figura 5.11 Deformação do Solo + Fibra PROMEX para esforço de tração ............ 42

Figura 5.12 Deformação do Solo + Fibra Cerâmica para esforço de tração.............. 42

Figura 5.13Fissuras nos corpos de prova submetidos a tração : (a) Solo Natural

(b)Solo com Fibra PROMEX (c) Solo com Fibra Cerâmica ..................................... 43

Figura 5.14 Curvas de cisalhamento para o solo natural ...................................... 43

Figura 5.15 Curvas de cisalhamento para o solo + Fibra PROMEX ........................ 43

Figura 5.16 Curvas de cisalhamento para o solo + Fibra Cerâmica .......................... 44

Figura 5.17 Curvas de cisalhamento para o solo natural ..................................... 45

Figura 5.18 Curvas de cisalhamento para o solo + Fibra PROMEX ....................... 45

Figura 5.19 Curvas de cisalhamento para o solo + Fibra Cerâmica ......................... 45

Figura 5.20 Envolvente de Ruptura (Energia Normal) ........................................ 46

Figura 5.21 Envolvente de Ruptura (Energia Intermediária) .................................. 47 


\section{Lista de Tabela}

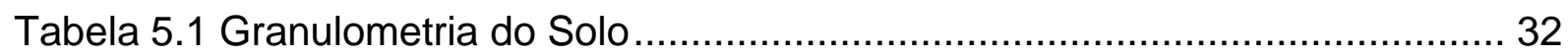

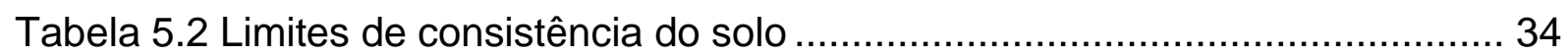

Tabela 5.3 Umidade ótima e peso específico máximo para cada energia de

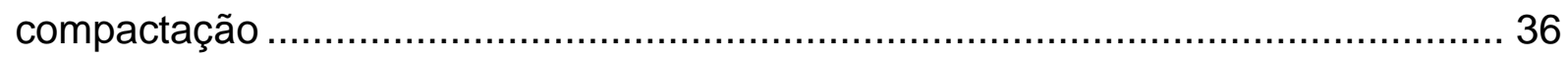

Tabela 5.4 Coesão e Ângulo de atrito para energia normal ................................... 46

Tabela 5.5 Coesão e Ângulo de atrito para energia intermediária........................... 47 


\section{INTRODUÇÃO}

O Brasil, dispondo de grandes indústrias de base que também são conhecidas como indústrias pesadas, são aquelas voltadas para a produção de equipamentos (indústrias de bens de capital) e matérias-primas processadas (indústrias extrativas) para outras indústrias. Os resíduos gerados pela fabricação desses produtos primários, são os maiores responsáveis por agressões fatais ao meio ambiente.

As indústrias de bens de capital, como as siderúrgicas, metalúrgicas produziram mais de 34,5 milhões de toneladas de aço, ferro, alumínio, cobre, titânio, em 2012. Dentro do mesmo grupo, temos as indústrias fabricantes de máquinas e equipamentos que utilizam em larga escala fibras cerâmicas, as quais segundo Evangelista (2011), são formadas por sílica e alumina que possuem um elevado ponto de fusão, resistência mecânica elevada, alta resistividade a temperatura e corrente elétrica. Devido a suas propriedades, este tipo de material é empregado para a vedação de fornos e estufas e vedação de tampas para inspeção em fornos e caldeiras. Após a fabricação desses equipamentos, são produzidos uma grande quantidade de resíduos de fibra cerâmica, que são descartados em muitas ocasiões inapropriadamente, constituindo um grave contaminante ao meio ambiente, devido ao seu processo lento de degradação e decomposição.

Ao mesmo tempo, as indústrias de bens de consumo, como as indústrias têxteis, também estabelecem um potencial poluidor ao meio ambiente. Segundo Finkler et.al., (2005), somente no sul do país foram gerados 44 Ton/dia de resíduos poliméricos, devido ao fato de que são descartados entre 20 e $35 \%$ de tecido por corte realizado. Dentre esses resíduos existem os resíduos de fibras sintéticas, como fibra NOMEX e a fibra protera, utilizadas para a formação da fibra PROMEX, que são empregadas no setor têxtil para a fabricação de roupas que necessitam de alta resistividade à temperatura, abrasão, e resistência mecânica, que são compostas de meta-aramida (poliamida) em longas cadeias aromáticas, segundo relatório da empresa DuPoint. Assim elevam sua resistência a efeitos externos de calor e altas temperaturas, sendo difíceis de serem degradados na natureza. 
A reciclagem dos resíduos sólidos gerados por essas indústrias, como as fibras, constitui um grande avanço para a preservação do meio ambiente, por ser um material com processo longo de decomposição, constituindo assim um potencial poluidor.

Conjuntamente a esse fato, existe a necessidade na engenharia geotécnica de incorporar materiais reciclados em seu meio, como a utilização de fibra reciclada como reforço de solo, para que sejam consumidos cada vez menos recursos não renováveis da natureza.

Deste modo, estudos foram realizados para inferir qual o teor ótimo de fibra que deve ser incorporado em uma massa de solo, para se obter melhor resistência a tração e a compressão. Assim, pesquisas foram desenvolvidas, como a caracterização de compósitos de poliamida e fibra de carbono, sendo observando uma maior resistência no composto solo argiloso - fibras recicladas (Botelho, 2002). Há também estudos sobre utilização de fibras de polipropileno visando o uso como base de fundações superficiais, comprovando o aumento da resistência a tração do solo, da resistência a deformação de ruptura e da tenacidade do compósito, em solos instáveis (Casagrande, 2001). Ainda há pesquisas que apontam a importância do uso de reforço de solo utilizando fibras, em seu teor ótimo, para solos com baixa resistência a tração, como os solos argilo-arenosos e argilo-siltosos ( Senol ,2012).

A presente pesquisa discorre sobre a utilização de fibras curtas recicladas: fibra cerâmica e fibra promex, em seu teor ótimo, cedidas pela empresa FlocosFibra, no reforço do solo laterítico do Distrito Federal, para avaliação do comportamento mecânico, de resistência a tração e a compressão, sem a adição de fibra e seu comportamento após a adição de fibra. 


\section{OBJETIVO}

\subsection{OBJETIVO GERAL}

Avaliar as mudanças no comportamento mecânico de um solo laterítico da região do Distrito Federal, após a adição das fibras recicladas: fibra cerâmica e fibra PROMEX.

\subsection{OBJETIVO ESPECÍFICO}

Estabelecer o teor ótimo de fibra cerâmica e fibra PROMEX, para aumentar a resistência mecânica do solo laterítico.

Definir as condições de compactação em laboratório, para o solo natural e com a adição de fibras recicladas.

Determinar as mudanças na resistência à compressão e à tração do solo laterítico com e sem adição de fibras.

Obter a resistência ao cisalhamento direto do solo natural e com a adição do reforço.

\section{FUNDAMENTAÇÃO TEÓRICA}

O Brasil que antes era um pequeno exportador de produtos primários, após a segunda guerra mundial, começou a ter sua economia voltada a industrialização. Logo, a partir de 1945, o cenário brasileiro começou a mudar, investindo cada vez mais em indústrias produtoras de matéria prima, para as demais indústrias, em 2012 sua produção chegou a cerca de 34,5 milhões de toneladas. Assim o descarte de resíduos sólidos foi inevitável, provocando uma agressão ao meio ambiente.

À frente da necessidade de controlar e gerenciar os resíduos, no 31 de maio de 2004 a ABNT publicou a nova versão da norma NBR 10.004 - Resíduos sólidos. Para classificar quanto aos seus riscos potenciais ao meio ambiente. Através dela podemos 
identificar o potencial poluidor do resíduo, classificando em três classes distintas são elas:

Classe 1: resíduos perigosos que afetam a saúde pública e o meio ambiente, exigindo tratamento e disposição especial em função das suas características de inflamabilidade, corrosividade, reatividade, toxidade e patogenicidade.

Classe 2: resíduos não inertes, não apresentam periculosidade, mas podem ter propriedades como combustibilidade, biodegradabilidade ou solubilidade em água.

Classe 3: resíduos inertes, apresentam solubilidade em água e conseguem deixar a água ainda potável, muitos desses resíduos são recicláveis. E apresentam dificuldades para se decompor no solo.

\subsection{RESÍDUOS INDUSTRIAIS}

\subsubsection{Resíduos siderúrgicos e metalúrgicos}

Segundo pesquisas realizadas sobre o complexo siderúrgico no brasil, o país ocupa a nona colocação mundial de produção de aço, e o setor de indústrias siderúrgicas produziu cerca de 3,8 milhões de toneladas de aço em 2012.

Diante da alta produção industrial brasileira, os resíduos sólidos foram acumulados e cada vez mais agredindo o meio ambiente. Segundo Cunha et.al., (2006), a indústria do aço foi responsável por 13,5 milhões de toneladas de resíduos, ocupando a classe 1 da norma segundo a NBR-10.004.

Souza (2006), Cita a criação das normas ISO voltada para a legislação ambiental causaram motivação para que as indústrias siderúrgicas e metalúrgicas investissem cada vez mais em pesquisas voltadas para o gerenciamento e tratamento de resíduos sólidos gerados por elas.

Assim diversas pesquisas surgem para incorporar esses resíduos a indústria da construção civil, com projetos de reutilização do material, em edificações sustentáveis. 


\subsubsection{Resíduos de indústrias de maquinas e equipamentos}

Este setor foi responsável por um faturamento em 2011 de 80 bilhões e entre os anos 2011 e 2014, e deve receber cerca de 3,3 trilhões e 268 bilhões em investimentos para os próximos anos, segundo a Associação Brasileira de Máquinas e Equipamentos. Assim pode-se perceber que o Brasil é um grande produtor de maquinaria industrial.

Perante a alta produção de maquinaria, a Associação Brasileira de Indústrias de Maquinas e Equipamentos, começou a estimular as indústrias a atingir $60 \%$ dos seus resíduos sólidos com tratamento e reciclagem adequada.

Assim, ocupando a classe 1 da norma NBR -10.004 sobre resíduos, dentre eles fibras cerâmica para a produção de fornos e caldeiras para a fabricação de materiais siderúrgicos, empresas conscientes do papel ambiental e também das vantagens econômicas e tecnológicas da reciclagem de resíduos buscam investir em estudos e pesquisas para o seu reaproveitamento.

\subsubsection{Resíduos de indústrias têxteis}

Conforme Finkler et.al., (2005), em indústrias têxteis é comum o uso de fibras sintéticas para a fabricação de roupas. O Brasil é um grande produtor mundial de artigos têxteis, ocupando a sétima colocação de produção de fios e tecidos e a terceira maior produção de malha.

Os resíduos gerados por essas indústrias a classe 1 segundo a norma, apresentam periculosidade ao ser descartado no meio ambiente. Segundo Finkler et.al., (2005), só no estado do Rio Grande do Sul (RGS) foram gerados cerca de 44 ton/dia de resíduos poliméricos. Considerando que no parque industrial de RGS, possuem cerca de 700 empresas têxteis, com uma produção média de 9 milhões de peças por ano. Gerando resíduos à base de $24 \%$ de fibra acrílica, $32 \%$ de poliéster e $44 \%$ de fibras mistas. Sendo assim, um valor significativo de resíduo de fibras produzido, diante da alta produção têxtil no sul do país, e que precisam de tratamento adequado perante $o$ seu alto nível de poluição. 


\subsection{FIBRAS RECICLADAS}

\subsubsection{Fibra cerâmica}

Essa fibra sintética é formada por sílica e alumina, obtida através da eletrofusão de seus compostos, a alumina inicialmente produzida para a fabricação de tubagens refratárias o que provoca alta resistência a alta e a baixas temperaturas, a densidade aparente e a porosidade. Já a sílica possui elevado ponto de fusão e também é um componente refratário.

A fibra cerâmica, mesmo após o processo de moagem na reciclagem, onde é passada em uma peneira de $1,2 \mathrm{~mm}$, tendo como resultado final pequenos filamentos da fibra , não perde suas características de resistência mecânica. $O$ anterior apresenta grandes vantagens econômicas, por ser uma fibra de baixo custo para reciclagem, aliado ao fator tecnológico das fibras sintéticas, ela é uma alternativa para a utilização de fibras recicladas na construção civil.

\subsubsection{Fibra PROMEX}

A fibra sintética PROMEX, exclusiva da empresa FlocosFibra, é obtida através da fusão de duas fibras têxteis chamadas fibra nomex e fibra protera, composta por longas cadeias aromáticas de poliamida (aramida), que apresentam alta resistência a abrasão, resistência a produtor químicos, e alta resistência mecânica, de compressão e tração.

Utilizadas na fabricação de roupas que necessitam de alta resistência, são facilmente em encontradas em vestimentas militares, como bombeiros e socorristas, e também eletricistas.

São fibras de baixo custo, que após seu processo de moagem na reciclagem passada em peneira 1,2mm, ainda conseguem manter suas características mecânicas. 


\subsection{REFORÇO DE SOLOS}

Entende-se como melhoria ou reforço de solos a utilização de processos físicos e/ou químicos que visam aperfeiçoar as propriedades mecânicas do solo, diminuindo a sua compressibilidade e sua permeabilidade. Assim através da estabilização muda-se certas características tornando-o adequado para aplicação em obras (JÚNIOR,2008). Utilizando-se este princípio várias formas de reforço de solos foram sendo criadas, para diversos fins geotécnicos como mostra a figura 1.1.

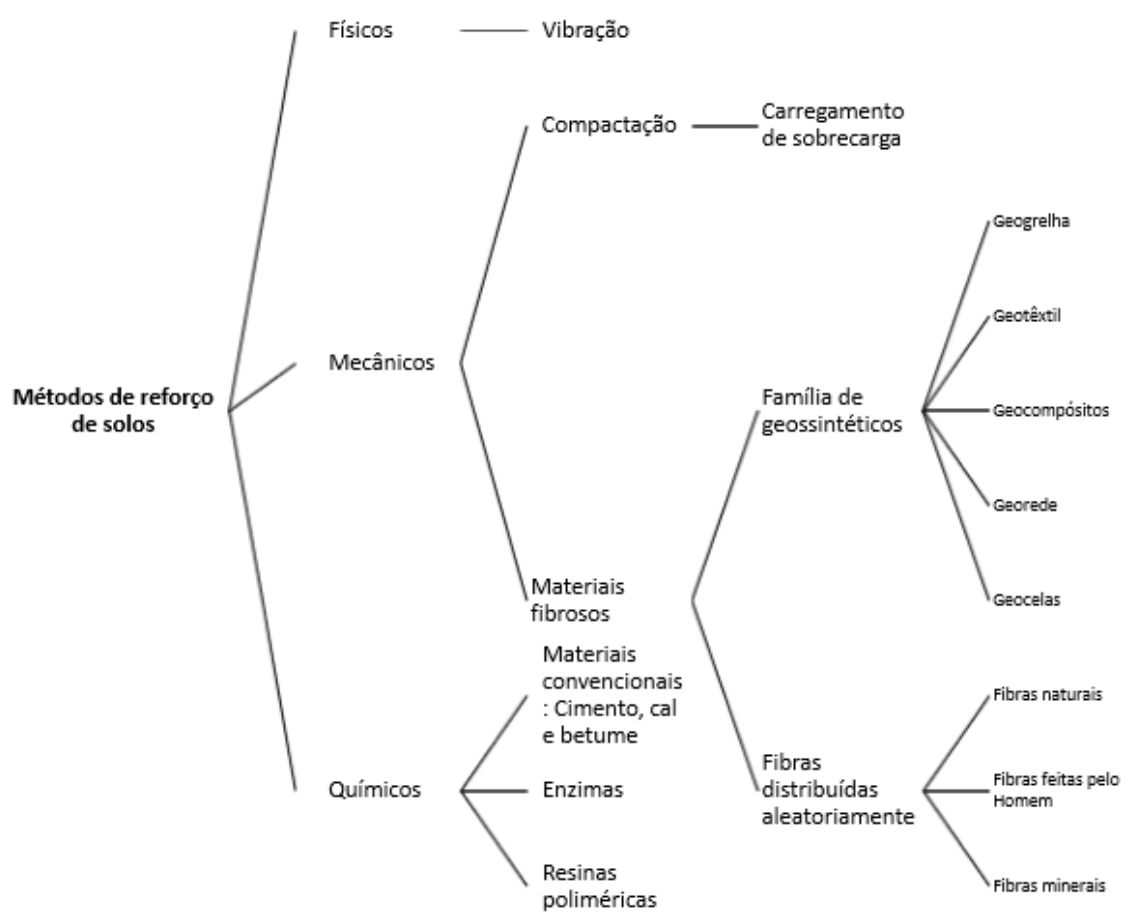

Figura 3.1 Métodos de reforço de solos. (DIAS, 2013).

Sendo uma técnica usada a milhares de anos, o reforço de solo é vastamente empregado pela humanidade. Em tempos antigos as hastes de bambu e junco eram utilizadas como um tipo de reforço para tijolos e solos granulares, com aplicabilidade em diversas obras. São também conhecidas aplicações de mantas de folhas e galhos inseridas sobre camadas de solos moles antes da construção de aterros no interior do Brasil (CASAGRANDE, 2005). 
Tendo como princípio que as raízes das plantas deixam solo mais estável, a utilização de fibras distribuídas aleatoriamente imita esse comportamento e melhora a resistência e a estabilidade do solo (DIAS, 2013). Mas essa técnica de reforço de solo através da incorporação de fibras, começou a ser estudado com mais atenção há pouco mais de três décadas segundo (CASAGRANDE, 2005).

Júnior apud Van Impe (1989) ressalta que esta estabilização de solos através do reforço pode ser dividida em três grupos:

Estabilização temporária: geralmente ocorre durante a execução de uma fase da obra, como o rebaixamento do lençol freático.

Estabilização permanente: Dura um longo período, geralmente toda a vida útil da obra, a técnica é a compactação do solo, de forma superficial e profunda.

Estabilização permanente com adição de material: combina a compactação com a adição de novos materiais, como fibras e geossintéticos.

Assim sendo o solo um material variável, dependente das condições climáticas de uma região ,para ser utilizado como base na construção pode não oferecer condições satisfatórias para esse fim, mas hoje se torna cada vez mais necessário a realização de obras em terrenos considerados inicialmente inadequado, seja pela baixa capacidade de suporte ou elevada compressibilidade é comum não conseguir atender algumas exigências de projeto (SILVA,2007). Por isso, um dos mecanismos utilizados a fim de fazer o melhoramento de solos foi a incorporação de fibras agindo como reforço, uma alternativa de baixo custo e alta viabilidade.

\subsubsection{Reforço de Solos com Fibras}

Esses materiais compósitos assim chamados por serem polifásicos que apresentam duas fases : as fibras e a matriz em que estão incluídas (SALES, 2011), em que essas matrizes sem adição de fibras , quando são submetidas a carregamentos surgem suas primeiras fissuras, sua abertura progressiva dá origem ao colapso da matriz rapidamente. Porém, em compósitos com a presença de fibra a fissuração é retardada (figura 1.2) tornando-se lenta , progressiva e menores e bem distribuídas pela matriz. 


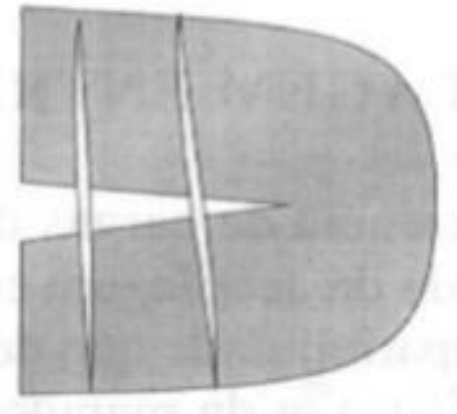

Figura 3.2Mecanismo para retardar as fissuras (Ferrante apud Sales ,2011)

As fibras fazem com que a matriz seja dúctil, ou seja, um material flexível, que pode se comprimir e demorar a se desintegrar por completo, contribuindo para aumentar a resistência pós-fissuração, a deformação de ruptura e tenacidade do compósito.

Então , Taylor apud Sales (2011), classificaram os principais parâmetros que devem ser observados, ao se tratar do compósito fibrossolo:

1) Quanto maior o teor de fibra no solo, maior será sua resistência pós-fissuração;

2) Quanto maior o módulo de elasticidade do material, maior a probabilidade da fibra se desprender da matriz;

3) Deve existir uma boa aderência entre a matriz e a fibra aplicada;

4) A resistência da fibra no compósito vai depender do teor de fibra e das propriedades de aderência fibra-matriz;

5) Quanto maior for o comprimento da fibra maior será sua resistência a uma tensão cisalhante.

Outro fator importante a ser observado é a geometria da fibra utilizada, pois aquelas mais extensíveis são mais influenciadas pelo comprimento e a fibra mais rígida pelo teor.

Assim , para a aplicação de estabilização permanente através da incorporação de fibras, em seu princípio foram empregadas fibras naturais, mas por existir limitações 
visíveis de perca de eficiência com o passar dos anos, e com o advento das indústrias químicas, os materiais sintéticos passaram a ser prioridade na aplicação, pois eram de fácil obtenção em grande escala e sua alta resistência a agente externos (TRINDADE, 2006).

\subsubsection{Reforço de Solos com Fibras Naturais}

Assim como visto da figura 1.1 esse tipo de reforço considerado mecânico a qual pertencem os geossintéticos e as fibras, se tornam grandes aliados para o aumento da resistência dos solos.

Como as fibras naturais, que ao serem aderidas ao solo como explica (GHAVAMI, K.; TOLEDO FILHO, R.; BARBOSA, N.,1998) em sua pesquisa, relata que através da incorporação das fibras de coco e fibras de sisal, com uma quantidade de $4 \%$, aumentam a resistência dos solos por meio da elevação das propriedades coesivas do solo, das forças de fricção por compressão que aparecem na superfície da fibra de reforço devido ao encolhimento do solo e do aumento da resistência ao cisalhamento do solo, dado à forma da superfície e à rugosidade das fibras. Mas por se tratar de uma fibra natural possui seu lado negativo ao ser utilizada, absorvendo água do solo , assim para que isso seja controlado é necessário ser estabilizada com outro material para garantir sua qualidade, além de estarem sujeitas a patologias geradas por fungos e bactérias.

Segundo (SALES, 2011) a adição de fibras naturais ao solo aumentou a capacidade de suporte do solo com o acréscimo de $0,5 \%$ de fibra, mas quando foi adicionado $0,25 \%$ o solo apresentou uma menor resistência, quando foi aferida sua resistência a tração houve uma significativa melhora quando comparado ao solo sem fibra, sendo retardado o processo de trincamento das amostras. Porém esse tipo de fibra apresenta algumas desvantagens, como por exemplo, a baixa durabilidade quando usada como reforço, a sua variabilidade de propriedades por ser um material orgânico e também possuir baixa adesão ao solo.

Para (LEOCÁDIO,2005), a inclusão de fibras de sisal alterou os parâmetros de compactação por ser uma fibra natural e absorve parte da água inserida. Através das 
porcentagens de 0,$25 ; 0,5 ; 0,75$ e 1 foram obtidos parâmetros referentes a resistência do solo aos esforços aplicados de cisalhamento direto podendo perceber que houve um aumento da resistência de pico para a $0,5 \%$ de fibra com comprimento de $15 \mathrm{~mm}$, sendo visto que seu aumento significativo foi observado para tensões mais elevadas, e ainda que o solo natural possui um comportamento mais frágil que o solo reforçado, em sua ruptura, apresentando uma queda maior de resistência pós pico sem a inclusão de fibras (figura 3.3) . mas o ângulo de atrito e a coesão permaneceram próximos ao do solo natural, já e o Índice de Suporte Califórnia foi visto que houve aumento da capacidade de suporte, para as diversas porcentagens aplicadas.

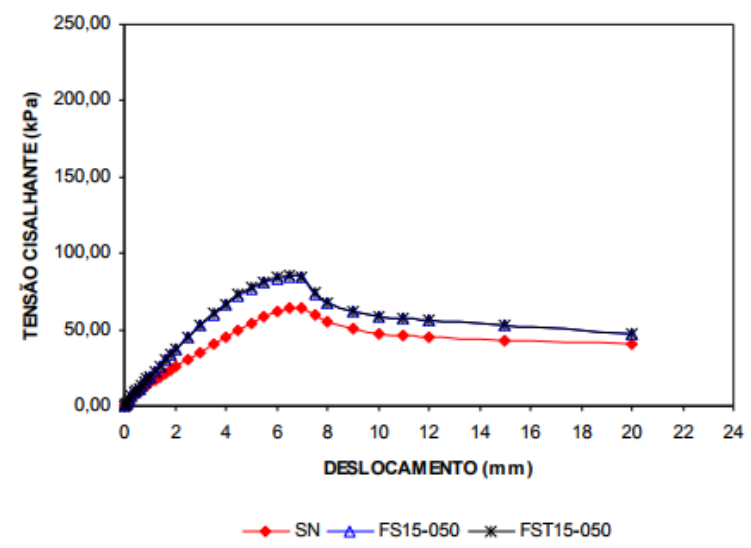

(a)

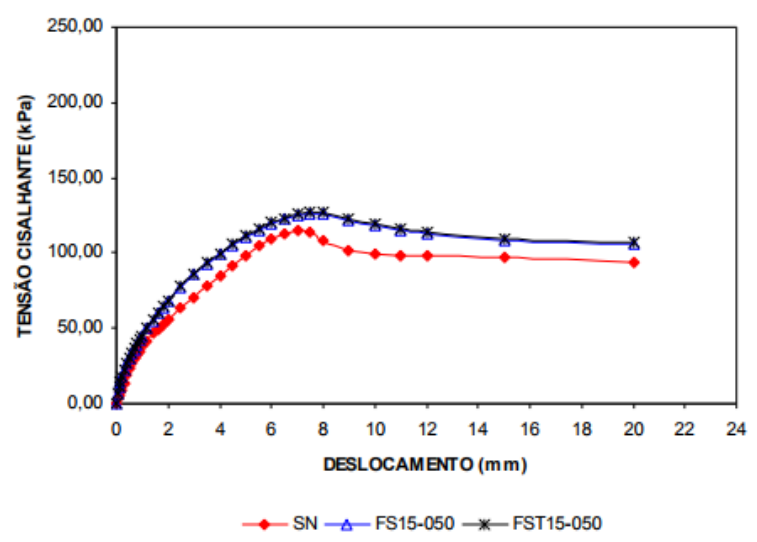

(b)

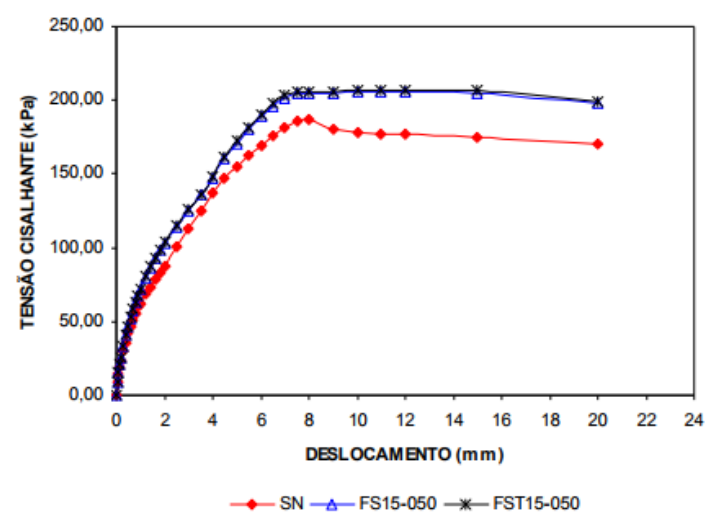

(c)

Figura 3.3 Resultado do ensaio de cisalhamento direto: (a) $50 \mathrm{KPa}$ (b) $100 \mathrm{KPa}$ (c) $200 \mathrm{KPa}$ (LEOCÁDIO, 2005) 
Já a curva de ruptura foi observado que o ângulo de atrito permaneceu próximo ao solo natural, mas sua resistência aumentou pois a coesão do solo apresentou uma melhora (figura 3.4).

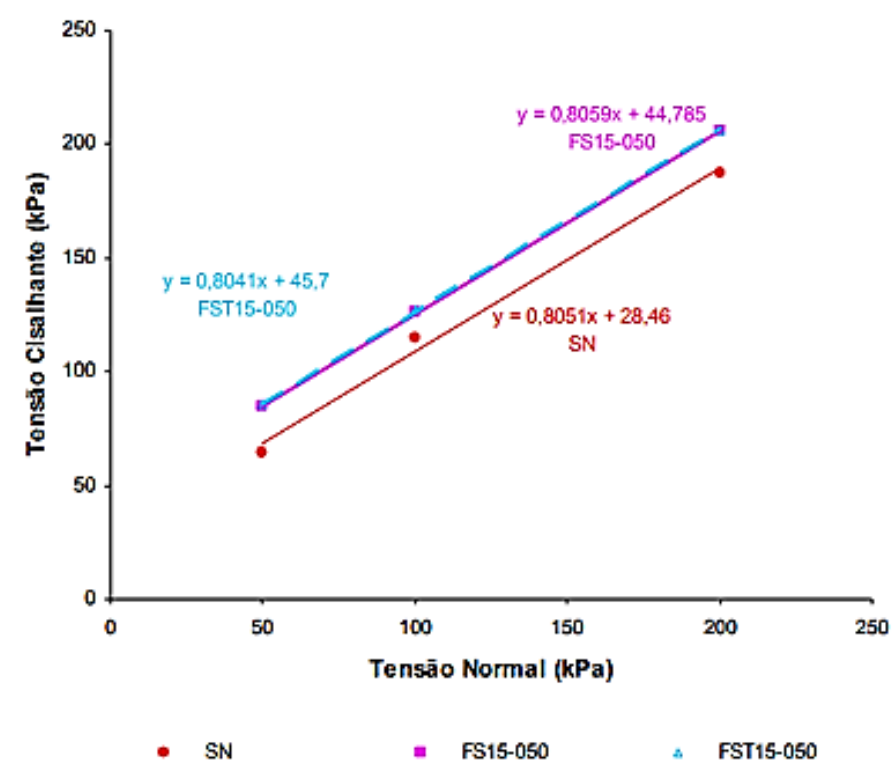

Figura 3.4 Envoltório de ruptura (LEOCÁDIO, 2005)

\subsubsection{Reforço de Solos com Fibras sintéticas}

(SENOL, 2012) Em sua pesquisa observou, que o uso de fibras é uma alternativa de baixo custo para reforço para aumentar a resistência mecânica a compressão simples de solos problemáticos e reduzir a expansão dos solos . Para a preparação dos corpos de provas foram utilizadas misturas distintas de solo-fibra, com adição 0,25\%, 0,5\% $, 0,75 \%, 1 \%, 1,25 \%$ de fibra em relação a massa de solo seca, para a compactação proctor com diferentes energias(normal, intermediária, modificada) e com diferentes teores de umidade, e depois foram realizados testes de resistência a compressão simples. Assim, ele observou que em solos argilo-siltosos e argilo-arenosos quando foram adicionados 0,5 e $0,75 \%$ de fibra houve um aumento da resistência a compressão, mas ao adicionar $1,25 \%$ de fibra o solo apresentou um decrescimento da resistência em relação as outras porcentagens de fibras.

(CASAGRANDE,2005) Observou que a técnica de reforço de solo com fibras vem ganhando cada vez mais espaço. Em sua pesquisa ele incluiu fibras de polipropileno através de uma distribuição aleatória no solo e observou o aumento da resistência aos 
ensaios de cisalhamento e triaxial, da ductilidade e da tenacidade e a diminuição da queda de resistência pós pico. As fibras atuaram no controle da abertura e do espaçamento entre as fissuras, distribuindo de forma uniforme as tensões da matriz, assim aumentando à resistência do solo. Relatando uma maior resistência ao cisalhamento com grande adição de fibra e notou que quanto maior o filamento da fibra, menor a sua contribuição para a resistência pós pico, pois as fibras curtas conseguem unir à superfície de ruptura, sendo verificado na figura 3.5 que a inclusão das fibras aumentou sua resistência, sendo confirmada pela figura 3.6 através do aumento da coesão e permanecendo com o ângulo de atrito próximo.

Para os ensaios triaxiais foi observada uma melhora no comportamento do solo reforçado sendo que a influência das fibras é verificada para baixas tensões confinantes, sendo maior a resistência quanto menor o diâmetro da fibra.

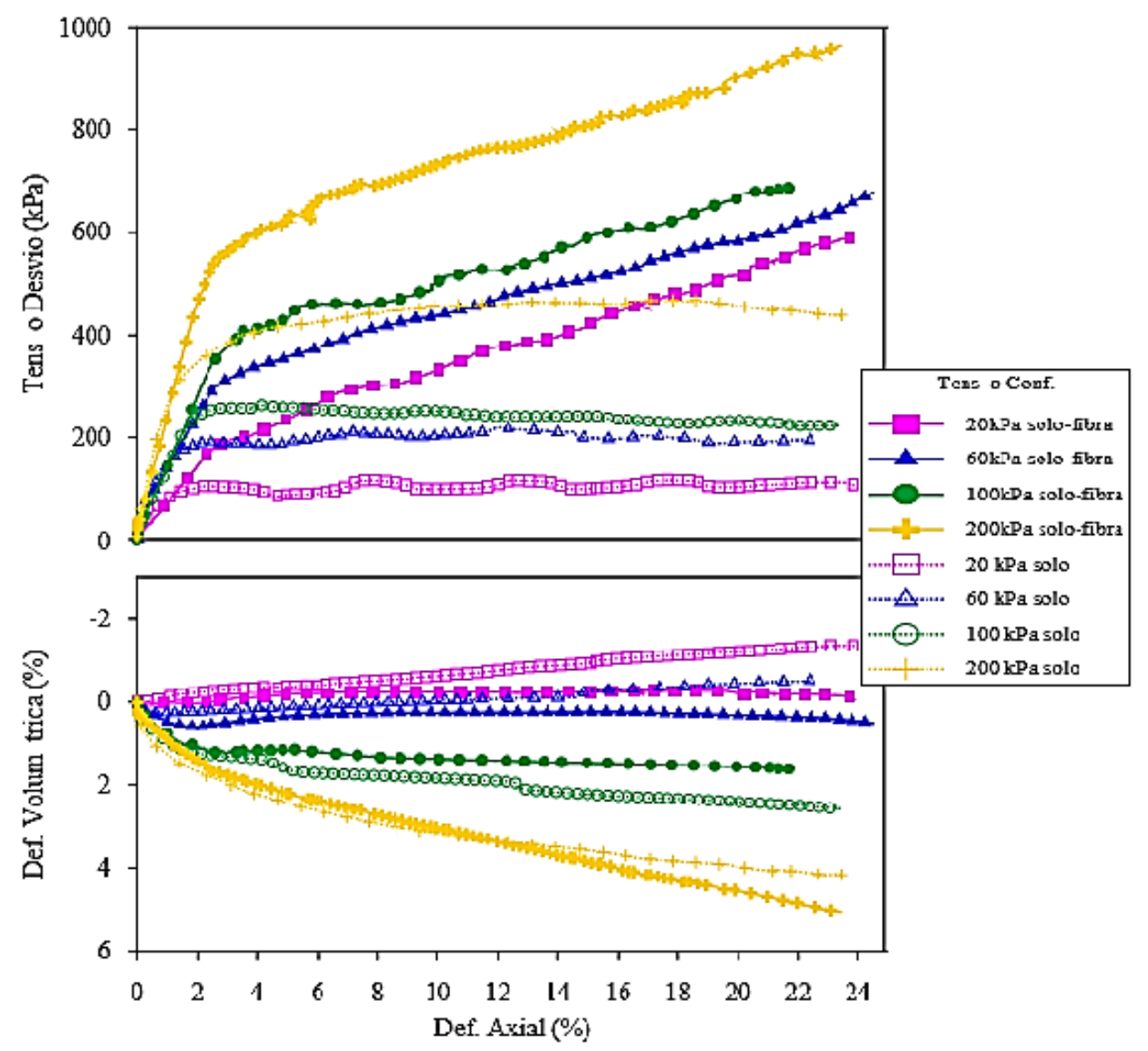

Figura 3.5 Deformação axial (CASAGRANDE, 2005) 


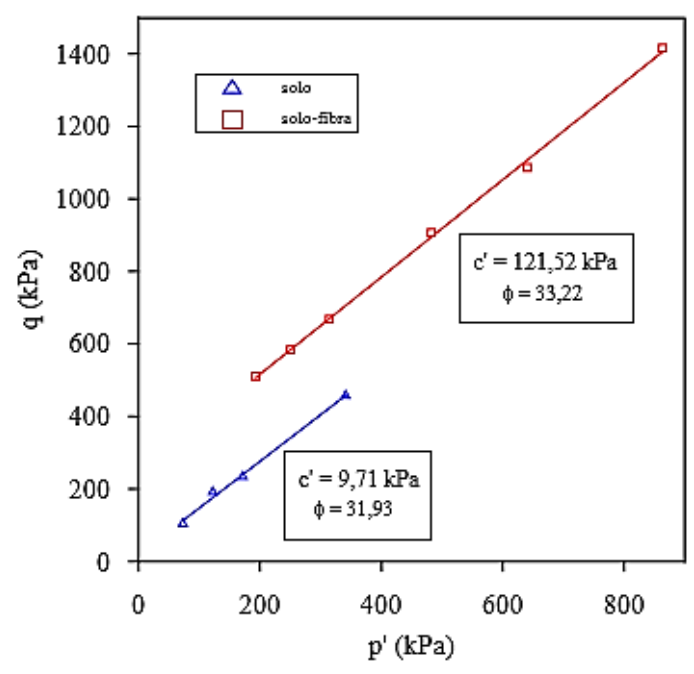

Figura 3.6 Curva de Ruptura (CASAGRANDE,2005)

Assim chegou a conclusão que o teor ótimo de fibra para solos argilo-siltosos é de 1\% e para argilosos é de $0,2 \%$.

(TRINDADE, 2006) nota em sua pesquisa que um solo predominantemente arenoso que foi reforçado com fibras de polipropileno e inseridas de forma aleatória, tinham comprimentos de 10, 15, 20 e $30 \mathrm{~mm}$, foram adicionadas com porcentagens de 0,25; 0,5; 0,75 em relação ao peso seco, e foram feitos ensaios de compressão não confinada e triaxiais consolidados drenados, chegando a conclusão que o comprimento das fibras é um fator determinante para a resistência do solo, onde os fios mais longos tornou o solo mais quebradiço, sendo importante ressaltar que não houve variações no peso específico seco máximo e na umidade ótima do solo, com as fibras inseridas. Ao final, notou-se que a porcentagem adicionada que teve o melhor resultado para os ensaios realizados foram aquelas com $0,75 \%$ de fibra com $20 \mathrm{~mm}$ de comprimento, apresentando uma melhor resistência a compressão e um aumento da tensão de pico e uma tendência de redução na queda e tensão pós pico em relação ao solo natural (figura 3.7) 


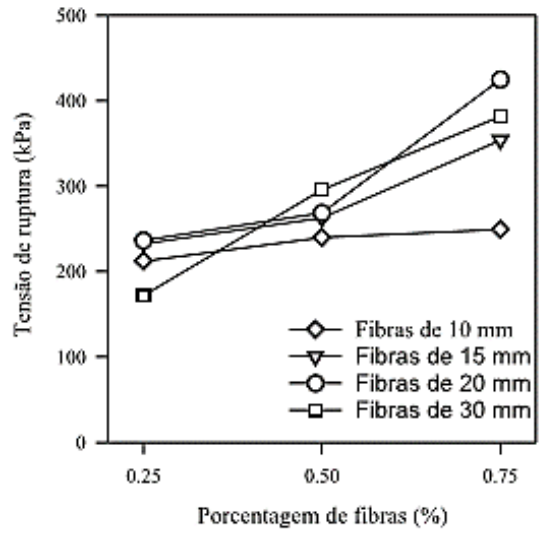

(a)

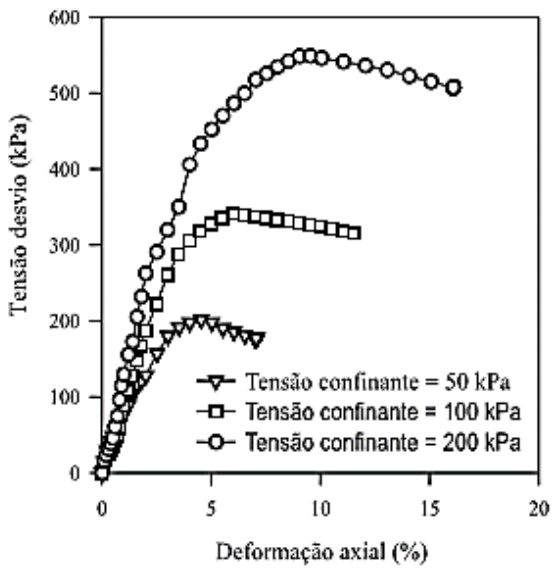

(b)

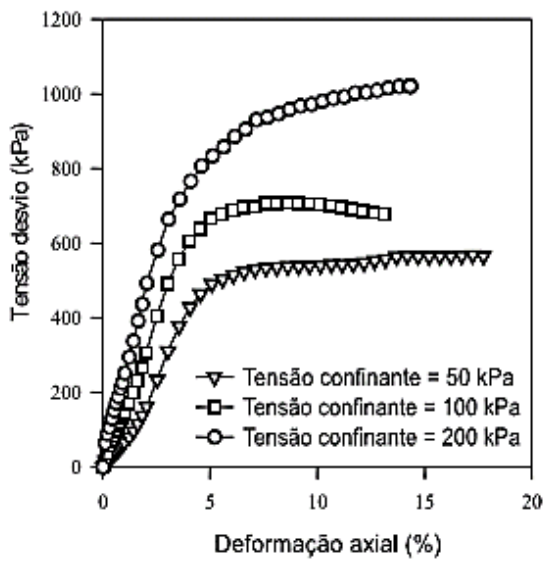

(c)

Figura 3.7 Ensaios realizados para verificar a resistência: (a) a compressão (b) ao triaxial sem reforço (c) ao triaxial com reforço (TRINDADE ,2006)

Nos estudos de (MUNTOHAR, 2013) notou -se que com a inclusão de fibras de polipropileno proveniente da reciclagem de sacolas plásticas com 2 a 2,5 mm de comprimento e uma porcentagem variando entre 0,$1 ; 0,2 ; 0,4 ; 0,8$ e $1,2 \%$ relativos à massa seca de solo, demostrou que a inclusão de fibras reduziu a fragilidade do solo estabilizado para ensaios de resistência à compressão, tração e cisalhamento, mostrando resultados satisfatórios com 0,4 a $0,8 \%$ de fibra, classificando o material como apropriado para a construção de camadas sub-base de pavimento. 
DIAS (2013) Observou o comportamento de um solo coesivo ao adicionar fibras de polipropileno com um diâmetro médio de $38 \mu \mathrm{m}$ com comprimento variando de 12,9mm e 49,56mm e adição de 0,6 \% a massa seca do solo, com adição de cimento Portland, foram realizados ensaios de compressão uniaxial e compressão diametral, chegando à conclusão que as fibras melhoraram a resistência a compressão uniaxial sendo este resultado totalmente influenciado pelo comprimento da fibra e a resistência a compressão diametral também é melhorada com o aumento da porcentagem de fibra.

(OLIVEIRA, 2016) Utilizando fibras recicladas de garrafa PET como reforço de solo, observou que ao adicionar uma porcentagem de $0,4 \%$ ao solo seco, afim de obter parâmetros relativos ao índice de suporte Califórnia notou que a inclusão das fibras ocasionou na diminuição da expansão do solo, pois elas preencheram os vazios e atuaram para favorecer a estruturação do solo.

\section{METODOLOGIA}

Para a realização deste projeto, foram estabelecidas nove etapas :

Etapa 1: Fundamentação Teórica

Etapa 2: Seleção e coleta dos materiais

Etapa 3: Caracterização dos materiais

Etapa 4: Determinação do teor ótimo de fibra

Etapa 5: Determinação das condições de compactação dos corpos de prova

Etapa 6: Elaboração dos Corpos de prova

Etapa 7:Determinação da resistência à compressão e tração

Etapa 8: Determinação da resistência a cisalhamento direto

Etapa 9: Avaliação e comparação dos resultados

A fundamentação teórica tem como objetivo embasar os estudos que serão realizados neste projeto. A segunda etapa tem como foco fazer a seleção e a coleta dos materiais 
através da obtenção de amostras representativas dos materiais utilizados na pesquisa: o solo laterítico e as fibras sintéticas recicladas : fibra cerâmica e fibra PROMEX. Na terceira etapa serão caracterizados os materiais, a fim de obter os parâmetros resistência do solo, e o tamanho médios dos filamentos de fibras utilizadas. Na quarta etapa será determinado o teor ótimo de fibra mediante estudos já realizados sobre adição de fibras sintéticas no solo. A quinta etapa tem como objetivo fazer a determinação de quais serão as condições ótimas para se realizar o ensaio de compactação do solo natural e do solo reforçado com as fibras sintéticas em estudo. Após, a partir dos parâmetros obtidos iniciará a sexta etapa, onde os corpos de prova serão elaborados em laboratório, com a adição das fibras e sem adição. Quando os corpos de prova estiverem prontos para serem utilizados dará início à sétima etapa, que será determinada a resistência à tração e a compressão dos corpos de provas, através de equipamentos estabelecidos, e determinar sua resistência a cisalhamento direto. Ao final será avaliado os resultados obtidos e comparados uns aos outros para obter o melhor parâmetro de resistência a tração e compressão do solo reforçado com fibras e do solo natural.

\subsection{FUNDAMENTAÇÃO TEÓRICA}

As pesquisas já realizadas foram estudadas e analisadas, para aferir o potencial poluidor dos resíduos de fibras gerados pelas indústrias brasileiras e sua importância para a reciclagem, afim de proporcionar um menor impacto ambiental, e serem reaproveitadas de forma correta na Engenharia Geotécnica. Após, foram feitas citações a artigos e dissertações sobre o uso de fibras naturais, e sintéticas para reforço de solo, para se obter os melhores parâmetros, e adicionar as fibras ao solo com intensão de aferir sua resistência à compressão, tração e cisalhamento direto.

\subsection{SELEÇÃO E COLETA DOS MATERIAIS}

\subsubsection{Coleta do Solo Laterítico}

O solo utilizado para execução desse projeto, possui características táctil-visual de um solo laterítico, encontrado em regiões tropicais. Foi coletado no Distrito Federal, sendo locado na Asa Norte, quadra 503 , propriedade pertencente a empresa Disbrave, hoje se encontra completamente construída (figura 4.1). O solo foi retirado de uma profundidade de quatro metros, como mostra a figura 4.2. 


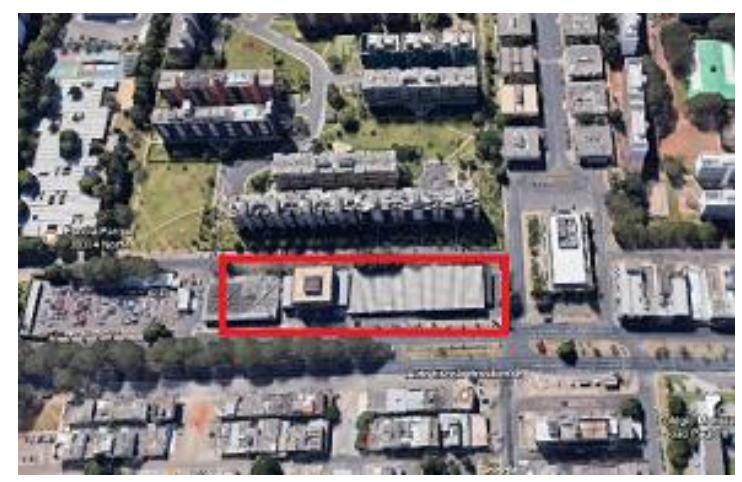

Figura 4.1 Localização da coleta de solo

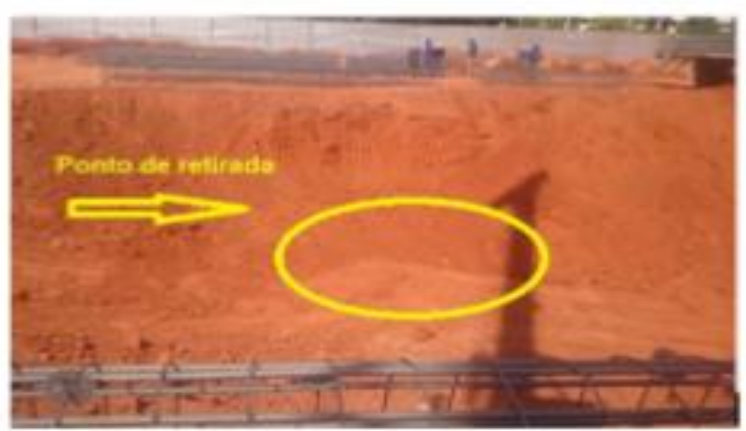

Figura 4.2 Local de retirada do solo utilizado

Então o material foi ensacado, vedado e devidamente referenciado. Após a coleta foi levado para o laboratório de solos e materiais de construção do UniCEUB, localizado na Asa Norte, para então serem feitos ensaios de caracterização , como limites de consistência, granulometria, massa específica, MCT-expedito e permeabilidade.

\subsubsection{Coleta das Fibras}

As fibras recicladas a serem trabalhadas foram as fibra cerâmica (figura 4.3 a ) e fibra PROMEX (figura 4.3 b ), doadas pela empresa de reciclagem FlocosFibra. A fibra cerâmica bastante utilizada para fabricação de maquinário, sendo escolhida devido a sua alta resistência e composição parecida ao do solo laterítico, contendo sílica e alumina. Já a fibra PROMEX foi selecionado devido a sua resistência química, física e mecânica a altas tensões de deformação utilizadas para fabricação de roupas, todas elas foram enviadas de São Paulo devidamente ensacadas e vedadas para evitar percas, e serem aferidas suas massas específicas. 


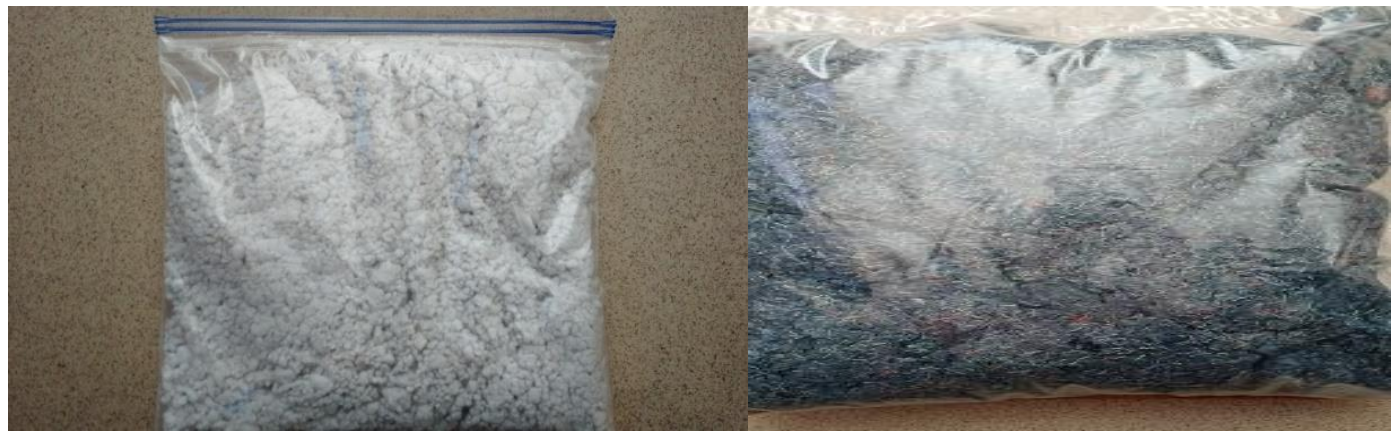

(a)

(b)

Figura 4.3 Fibra utilizadas (a) fibra cerâmica (b) fibra PROMEX

\subsection{CARACTERIZAÇÃO DOS MATERIAIS}

\subsubsection{Caracterização do Solo}

Para a caracterização do solo, foi necessário preparar a amostra segundo a NBR 6457 para os ensaios de granulomentria, Limites de Atteberg e massa específica dos grãos passantes na peneira 4,8mm , os quais foram realizados nesta pesquisa. Afim de obter a granulometria do solo segundo a NBR 7181, foi secado ao ar livre até atingir a umidade higroscópica, em seguida passado na peneira 4,8mm para posteriormente realizar o peneiramento grosso (figura 4.4 a ) e sedimentação da parte fina do material (figura $4.4 \mathrm{~b}$ ).

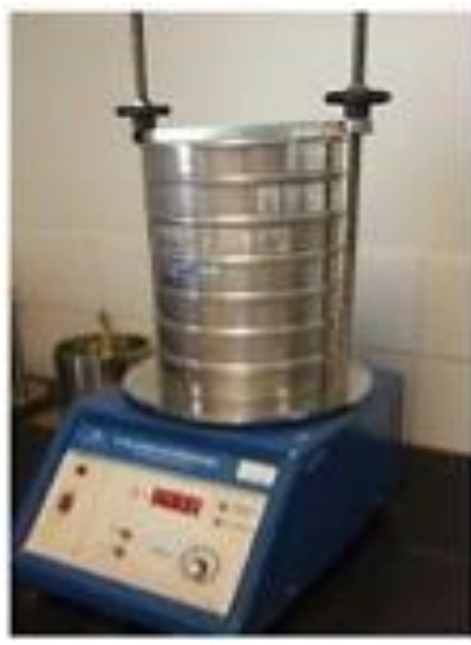

(a)

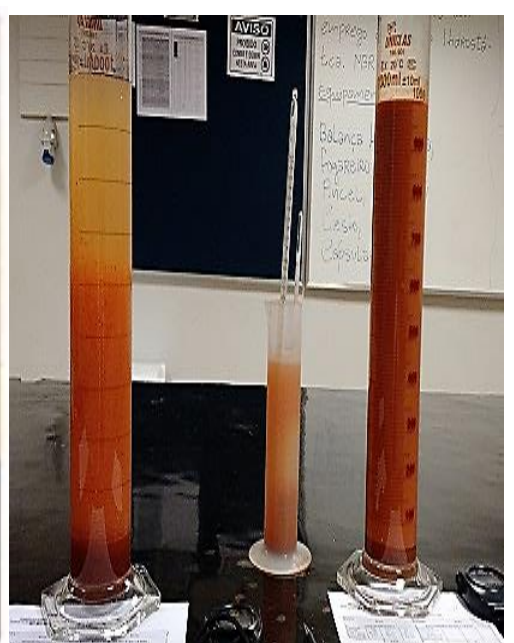

(b) 
Figura 4.4 Etapas do ensaio de granulometria (a) Peneiramento do material grosso

(b) Sedimentação da parte fina

Para o ensaio de determinação massa específica real dos grãos, foi utilizada a NBR 6508 (figura 4.5)

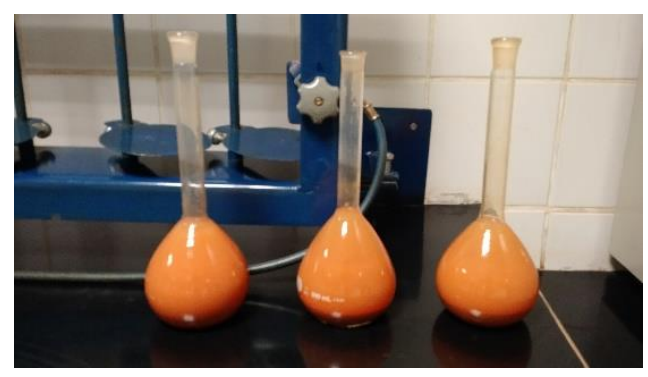

Figura 4.5 Ensaio de Massa Específica

Foi feito a classificação segundo a identificação e descrição expedita - metodologia MCT , sendo considerado um ensaio rápido, realizado in loco ou em laboratório, é possível obter as propriedades do solo, com sua consistência, a resistência no estado seco e se ocorre expansão com a presença de água ou contração, sendo utilizado para a caracterização de solos lateríticos encontrado em regiões de clima tropical.

Os limites de Atteberg foram determinados segundo a NBR 6459 para o limite de liquidez buscando alcançar a umidade equivalente para realizar 25 golpes com o equipamento de Casa Grande e estabelecer a transição entre o estado plástico e líquido (figura 4.6).

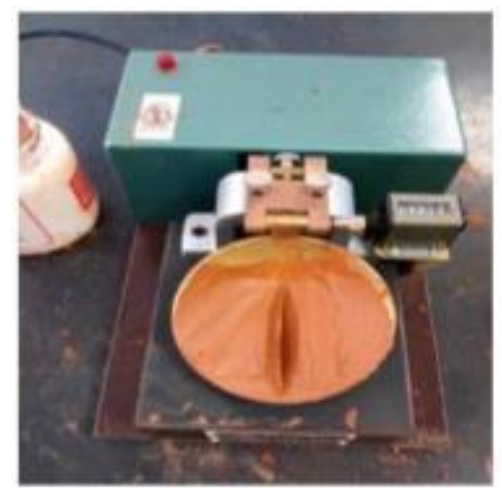

Figura 4.6 Equipamento de Casa Grande para determinar limite de liquidez E o limite de plasticidade foi aferido segundo a norma NBR 7180 , através de pequenos rolinhos com $30 \mathrm{~mm}$ de diâmetro e $100 \mathrm{~mm}$ de altura, é retirada a umidade quando eles começam a se fissurar (figura 4.7) 


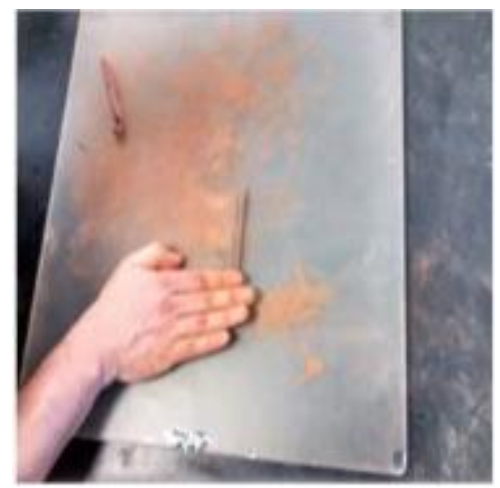

Figura 4.7 Determinação do limite de plasticidade

\subsubsection{Caracterização das fibras}

\subsubsection{Fibra Cerâmica}

Foram escolhidas por apresentarem uma alta resistência e baixo custo após serem recicladas, contando com alta resistência térmica e química, são utilizadas para fabricação de materiais que necessitam de excelente durabilidade. Sendo ainda constituída de sílica e alumina, compostos que podem ser encontrados em solos muito lixiaviados, como o solo laterítico.

Assim para que as fibras que foram doadas em flocos (figura 4.3 a), pudessem se adaptar melhor ao solo, foram peneiradas na peneira de №60 (figura 4.8) realizados ensaios de massa específica com o equipamento pentapicnômetro (figura 4.9), cedido pela Universidade de Brasília.

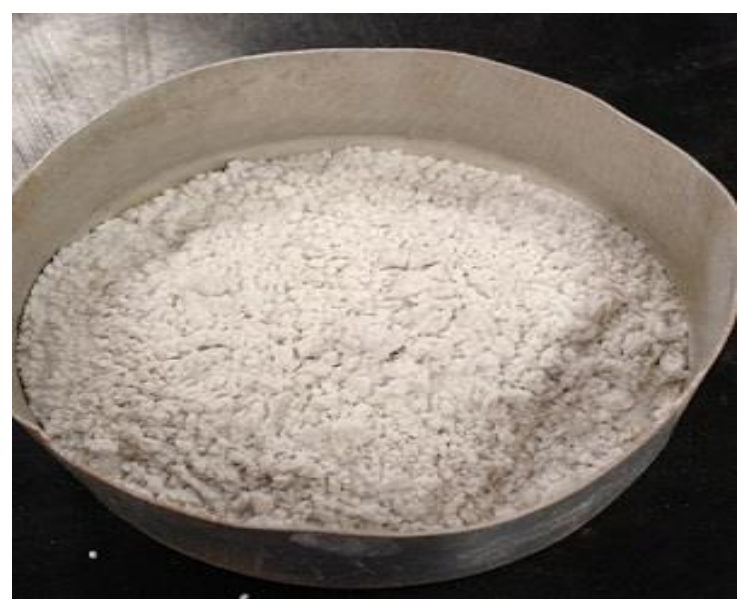


Figura 4.8Fibra passada na peneira ํ60

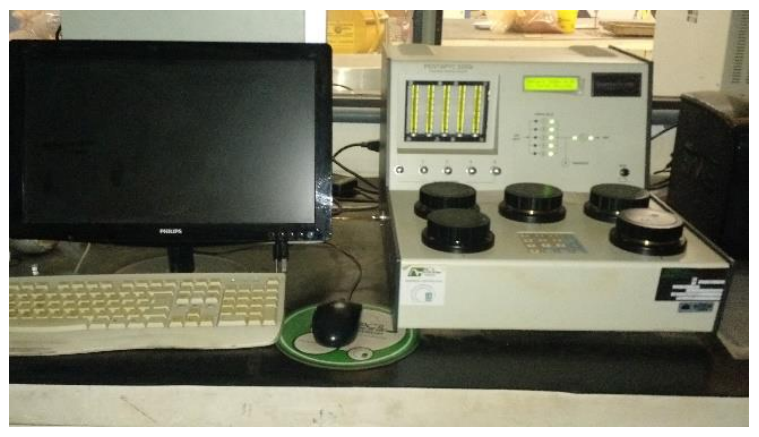

Figura 4.9 Equipamento pentapicnômetro

\subsubsection{Fibra PROMEX}

A fibra PROMEX sendo uma mistura de dois tipos de fibra a protera e a nomex, utilizadas para a fabricação de roupas de alta resistência a abrasão e produtos químicos. Foram moídas segundo o fabricante em tela de 1,2 $\mathrm{mm}$ com medidas variando entre 0,2 $\mathrm{mm}$ e $3 \mathrm{~mm}$ (figura 4.10), foram adicionada ao solo sem nenhum outro tipo de peneiramento. E aferida a sua massa específica através do pentapicnômetro (figura 4.9).

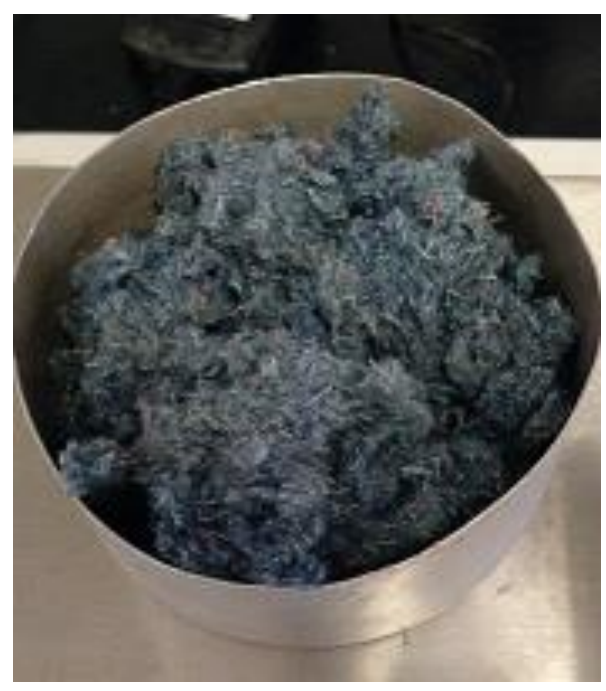

Figura 4.10 Fibra PROMEX 


\subsection{DETERMINAÇÃO DO TEOR ÓTIMO DE FIBRA}

A partir da fundamentação teórica exposta nesse projeto, foi mensurado qual seria o melhor teor de fibra a ser adicionada ao solo, para aumentar sua resistência . Foi então concluído que a porcentagem ideal seria de $0,5 \%$ de fibra em relação a massa seca do solo em estudo, para cada fibra adotada separadamente.

\subsection{DETERMINAÇÃO DAS CONDIÇÕES DE COMPACTAÇÃO DOS CORPOS DE PROVA}

Foi escolhido trabalhar com o solo em seu peso específico máximo e sua umidade ótima foram realizados ensaios de compactação segundo as normas NBR 6457 e 7182, para a determinação desses parâmetros.

Para a inclusão de fibras sendo importante ressaltar, que por se trabalhar com material sintético sua absorção de água é desprezível pois são impermeáveis, comprovado através da tentativa de imersão delas em água por 48 horas, como aconteceu com a fibra cerâmica na figura 4.11, que permaneceu na superfície da água durante todo o tempo.

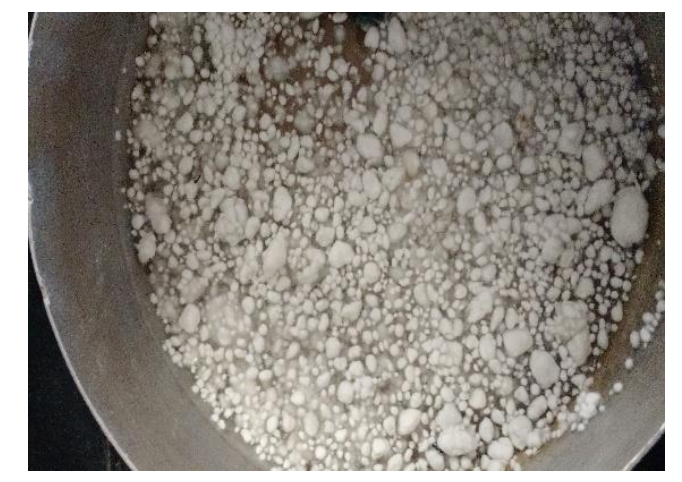

Figura 4.11 Tentativa de imersão em água da fibra

Para a compactação dos corpos de prova, afim de se determinar a resistência à compressão e a tração do compósito, o solo foi passado na peneira de n10 e as fibras foram misturas de forma aleatória (Figura 4.12). 


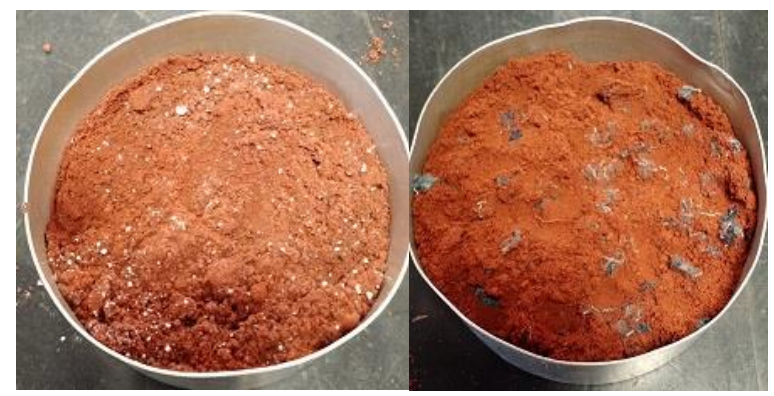

(a)

(b)

Figura 4.12 Fibras aleatoriamente distribuídas no solo : (a) fibra cerâmica; (b) fibra PROMEX

Após a mistura foi adicionado água destilada até atingir a umidade ótima para cada energia de compactação : normal, intermediária e modificada. Foram ensacadas, lacradas e identificadas (figura 4.13), e deixadas em repouso durante 24 horas para que o solo ficasse uniformemente úmido.

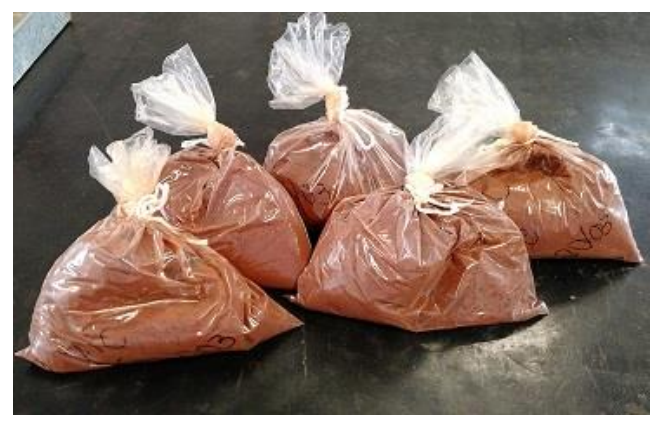

Figura 4.13 Amostras ensacadas

\subsection{ELABORAÇÃO DOS CORPOS DE PROVA}

O solo inicialmente foi seco ao ar até atingir a umidade higroscópica. Após foi peneirado na peneira de № $10(2 \mathrm{~mm})$.

Já as fibras recicladas que foram doadas em forma de flocos, foram peneiradas. $A$ fibra PROMEX na malha $1,2 \mathrm{~mm}$ pelo fabricante e a fibra cerâmica na malha $0,25 \mathrm{~mm}$, em laboratório, para ser trabalhada na forma de pó. 
Para a compactação do solo reforçado, foi determinada a massa de fibra necessária para obter uma porcentagem de 0,5 em relação a massa de solo seca. Após foram pesadas em uma balança com precisão de $0,01 \mathrm{~g}$, e foram inseridas.

Afim de determinar a quantidade de material para a elaboração dos corpos de prova para os ensaios de resistência à compressão e a tração, os cálculos foram baseados nas condições ótimas de peso especifico seco máximo e umidade ótima, obtidas através dos ensaios de compactação Proctor para as três energias estabelecidas (normal, intermediária e modificada).

Após determinar a quantidade de solo e fibra a ser utilizada, foi iniciado o processo de mistura e homogeneização dos materiais. Sendo observado que a fibra cerâmica apresentou uma boa adaptação a massa de solo seca, já a fibra PROMEX não apresentou boa homogeneização no estado seco, somente adaptou-se ao solo com a inserção de água destilada, como é visto na figura 4.14.

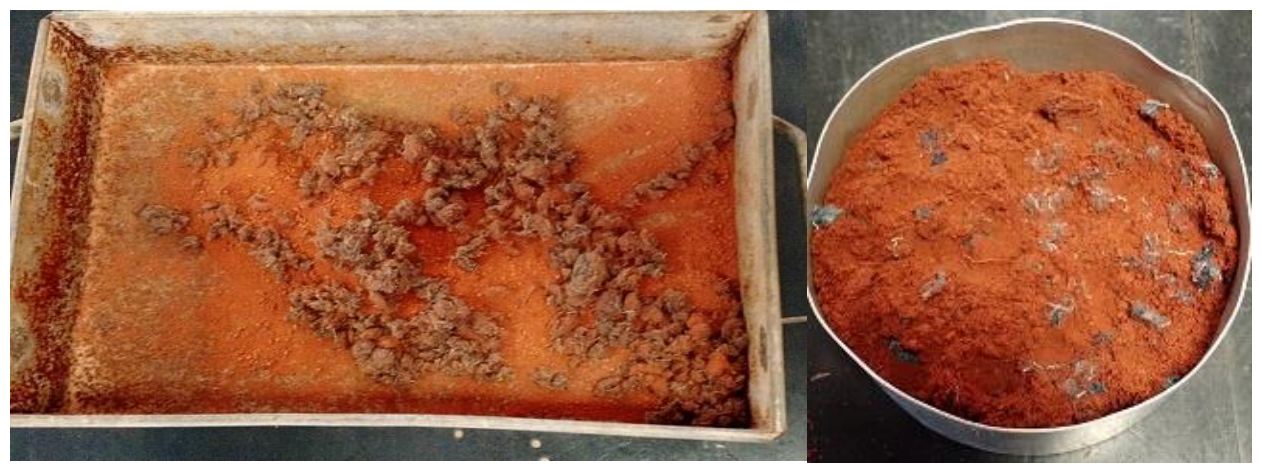

(a)

(b)

Figura 4.14 Adaptação da fibra PROMEX ao solo (a) sem adição de água (b) com adição de água

Em seguida o solo em sua umidade ótima foi dividido em cinco cápsulas, referentes as cinco camadas do corpo de prova, com a sobra foi feito o controle de umidade.

Antes de realizar a compactação dos corpos de prova foram preparados os equipamentos e acessórios segunda a figura 4.15. Essas peças foram lubrificadas com vaselina para facilitar o trabalho de desformar os CPs, e não ficar solo retido nas paredes metálicas. 


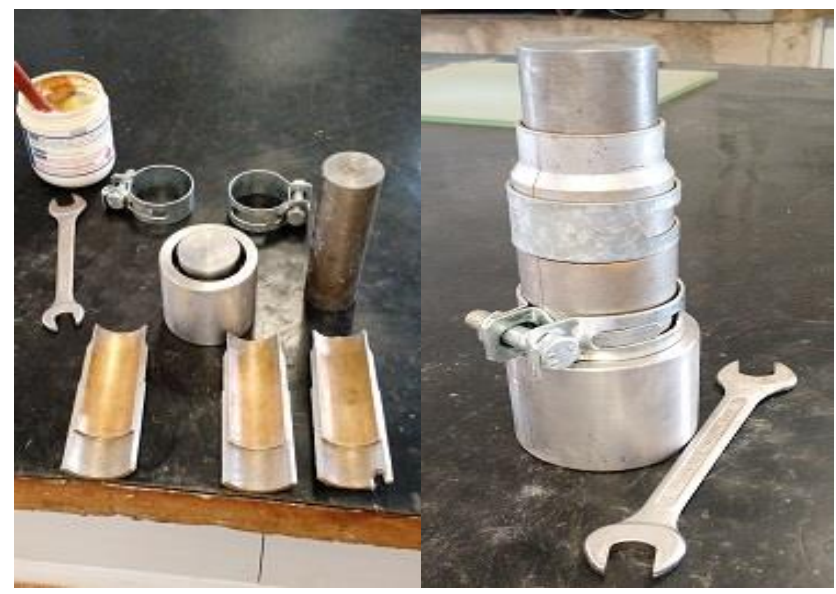

(a)

(b)

Figura 4.15 Equipamento para compactação (a) materiais para compactação (b) cilindro pronto para começar os ensaios

O molde foi montado (figura 4.15 b) e apertado por meio de braçadeiras grossas e parafusos, até o ponto que as paredes ficassem bem unidas. Após colocou-se um papel filtro no fundo para evitar que solo ficasse no local.

Após a preparação dos materiais e dos equipamentos necessários iniciou-se a moldagem dos corpos de prova. Utilizando um funil, para evitar percas, o material foi inserido no molde.

No cilindro de compactação foram marcados com caneta permanente as limitações de cada camada de solo para os ensaios de resistência a compressão, sendo também controlado o número de golpes e a carga aplicada.

A compactação foi feita através do uso de prensa estática com capacidade para 150 KN (figura 4.16) com uma célula de carga com sensibilidade de 20.000 kgf acoplada a ela para que a carga aplicada sobre os corpos de prova seja controlada. 


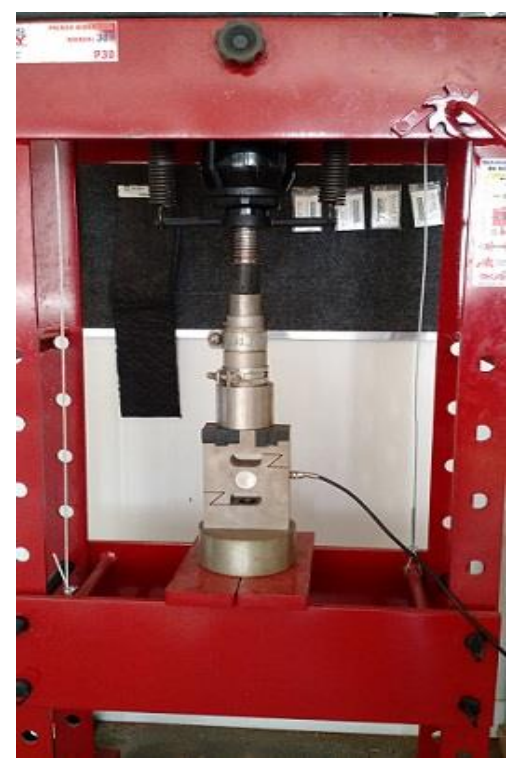

Figura 4.16 Prensa Estática

Após a compressão da primeira camada, o molde foi levado para uma bancada, e adicionou-se mais solo, referente a segunda camada, para ser compactada sobre a primeira, e assim seguiu até serem compactadas as cincos camadas uma sobre as outras até atingir uma altura de 100 mm, para os ensaios de resistência a compressão simples. Para esse fim foram elaborados de três a quatro corpos de prova.

Para realizar os ensaios de resistência à tração os corpos de prova foram moldados em uma única camada de $20 \mathrm{~mm}$, empregando a mesma metodologia utilizada para ensaios de resistência à compressão simples.

Ao término do processo de compactação dos corpos de prova, foi iniciado a retirada das amostras do molde. As contenções laterais que eram presas por braçadeiras e parafusos foram afrouxadas, o corpo de prova foi girado para que ficasse em cima do cilindro de compactação. Em seguida as paredes foram cuidadosamente removidas, tomando todos os cuidados necessários para que não danificasse as amostras (figura 4.17) 


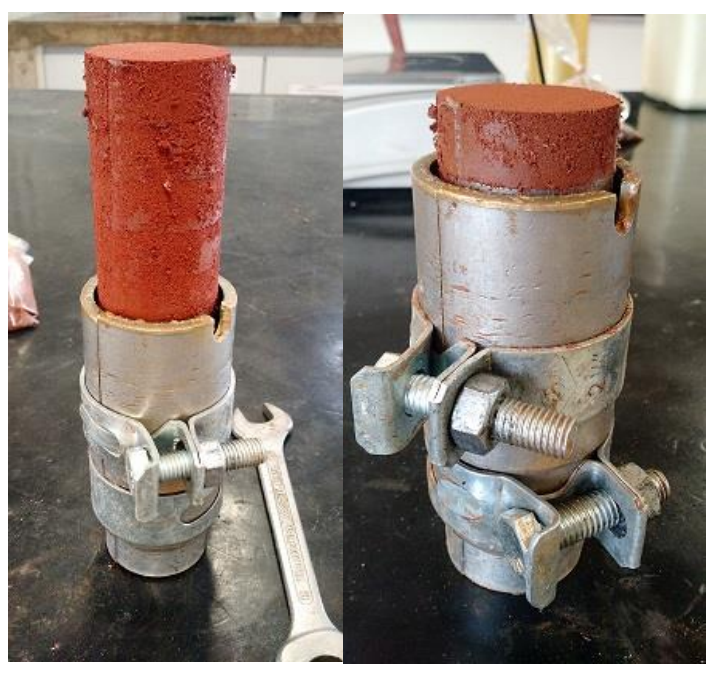

(a)

(b)

Figura 4.17 Corpos de prova compactados (a) corpo e prova para ensaio de compressão simples (b) corpo e prova para ensaio resistência a tração

Ao serem retiradas as amostras do molde de compactação, afim de perder pouca umidade os corpos de prova foram embaladas em papel filme ( figura $4.18 \mathrm{a}$ ), em papel alumínio ( figura 4.18 b) e identificados, ao final foram guardados em uma caixa térmica envolvida com papel alumínio (figura $4.18 \mathrm{c}$ ).

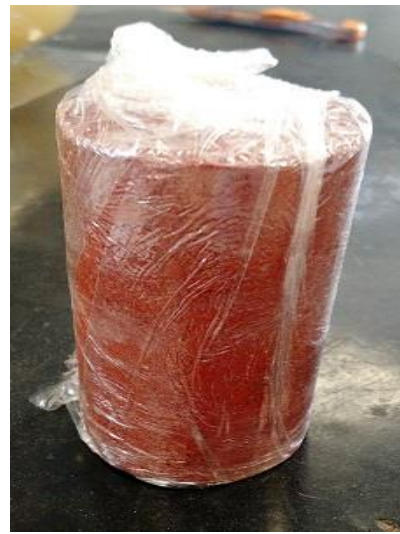

(a)

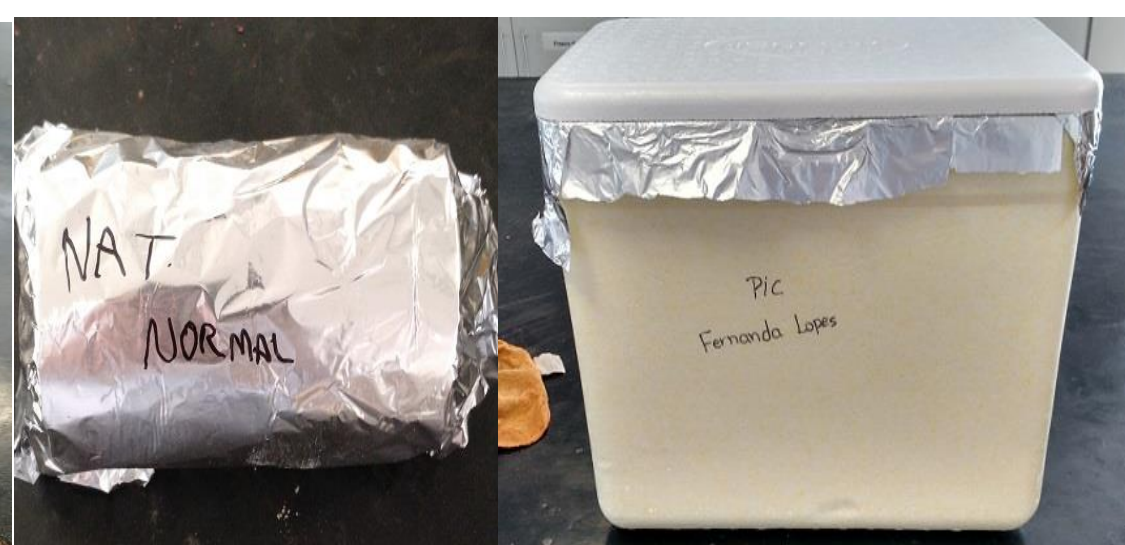

(b)

(c)

Figura 4.18 Embalagem dos corpos de prova (a) embalado em papel filme (b) embalado em papel alumínio (c) caixa térmica para armazenamento 


\subsection{DETERMINAÇÃO DA RESISTÊNCIA À COMPRESSÃO E A TRAÇÃO}

Para estabelecer a resistência a compressão dos corpos de prova (CPs) feitos com solo natural e solo reforçado com fibras, foi utilizada a norma NBR 12770/92, sendo eles desembalados e mensurados seu tamanho com um paquímetro digital (figura 4.18) e peso em balança com precisão de $0,01 \mathrm{~g}$, para certificar a perda de umidade dos CPs.

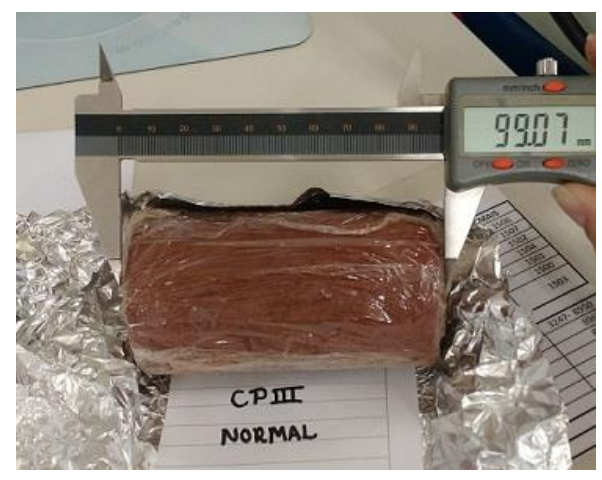

Figura 4.19 Medidas dos corpos de prova

Para o ensaio de resistência a compressão, os corpos de prova foram colocados e um equipamento da CONTENCO (figura 4.19) com marcadores digitais, onde foi estabelecida a velocidade de deslocamento vertical em $1 \mathrm{~mm} / \mathrm{min}$ e mensurada a carga juntamente com o deslocamento.

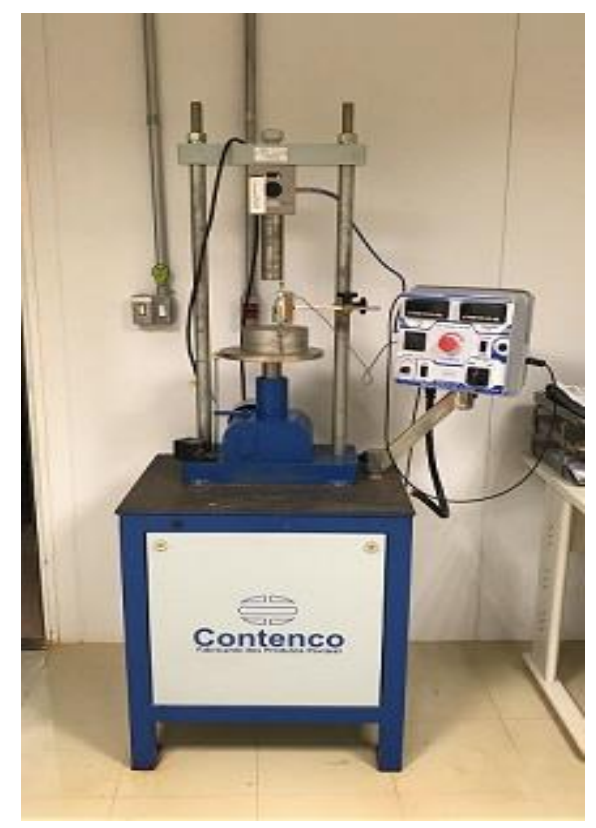


Figura 4.20 Máquina utilizada para rompimento dos corpos de prova

A partir dos resultados obtidos, foi calculada a resistência à compressão para os corpos de prova rompidos, empregando as equações estabelecidas pela norma NBR 12770.

Para os ensaios de resistência a tração foi usado o mesmo equipamento da CONTENCO (figura 4.19), acoplado com uma célula de carga com maior sensibilidade de $2 \mathrm{kN}$, e pequenos suportes para o corpo de prova, ser centralizado para ocorrer o rompimento(figura 4.20), segundo a norma DNER -ME 181/94, os corpos de prova foram pesados e medidos com um paquímetro digital, para ser aferida a perca de umidade, e submetidos a uma velocidade de deslocamento vertical de $1 \mathrm{~mm} / \mathrm{min}$, e mensuradas as cargas e o deslocamento ocorrido.

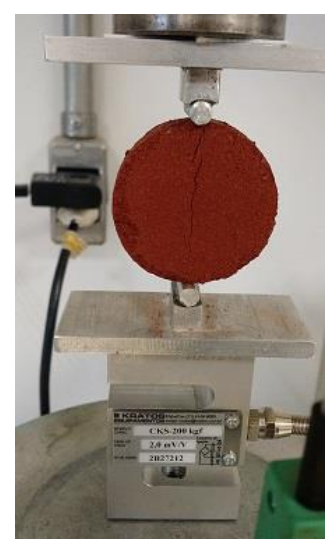

Figura 4.21 Determinação da resistência à tração

Após é verificada a massa específica aparente de cada corpo de prova através do uso de balança hidrostática segundo a norma NBR 10838.

Ao final os dados foram plotados em uma planilha e aferidas as resistências dos corpos de prova á tração.

\subsection{DETERMINAÇÃO DA RESISTÊNCIA AO CISALHAMENTO DIRETO}

Para a determinação da resistência ao cisalhamento direto, o solo foi seco ao ar até atingir a umidade higroscópica, após os corpos de prova foram compactados nas energias normal e intermediária segundo as normas NBR 6457 e 7182, com a 
umidade ótima e peso específico seco máximo do solo em estudo com e sem adição de fibra.

Para iniciar o ensaio, os corpos de prova foram moldados e colocados na máquina utilizada para cisalhamento direto (figura 4.21) segundo a norma ASTM D3080.

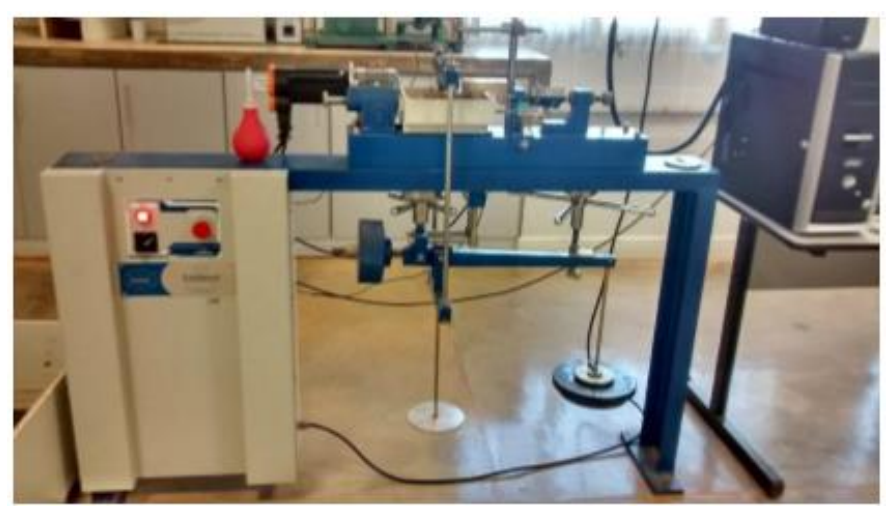

Figura 4.22 Máquina de cisalhamento direto

Foram realizados com cargas de $100,200,300$ e $400 \mathrm{kPa}$, de forma saturada, com adensamento para corpos de provas compactados na energia normal de 2 horas e cisalhamento com uma velocidade de deslocamento horizontal de $0,058 \mathrm{~mm} / \mathrm{min}$. Para os corpos de prova compactados na energia intermediária o adensamento foi de 1h 30 min, e manteve-se a velocidade estabelecida.

\subsection{ANÁLISE E COMPARAÇÃO DOS RESULTADOS}

Ao final dos ensaios realizados, todos os dados foram plotados em planilha do programa Microsoft Excel, feitos gráficos comparativos entre a resistência à compressão, tração e cisalhamento direto dos compósitos em relação ao solo natural a fim de determinar qual foi o aumento resistência ao ser adicionada as fibras.

\section{RESULTADO E DISCUSSÃO}

Nesta etapa serão apresentados os resultados e discutidos os ensaios referentes a caracterização do solo e das fibras, e seu comportamento com a adição das fibras 
cerâmica e PROMEX como forma de contribuição para o aumento da resistência à compressão, a tração e cisalhamento direto.

\subsection{CARACTERIZAÇÃO DO SOLO}

\subsubsection{Granulometria}

O ensaio para determinação da granulometria do solo foi feito segundo a norma NBR 7181 (figura 5.1)

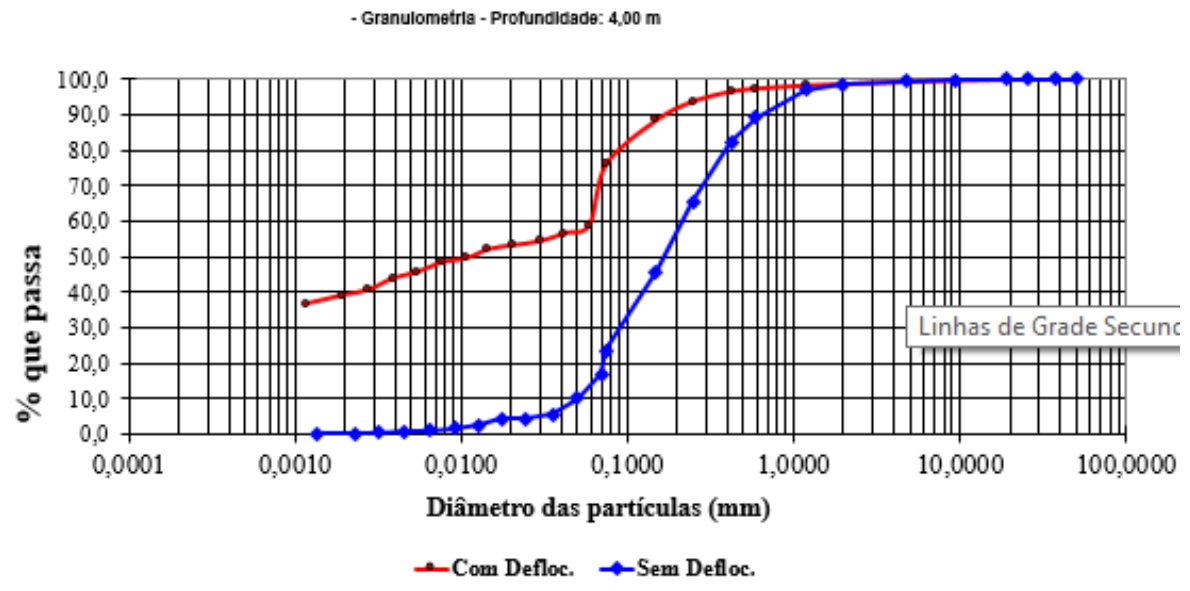

Figura 5.1Granulometria do solo

Sendo assim , o solo foi classificado segundo o Sistema Unificado de Classificação de Solo (SUCS) como uma argila de baixa plasticidade com areia - CL e no Sistema de Classificação Rodoviária como um solo do tipo A-7-5 (10).

Na tabela 5.1 é apresentada a composição granulométrica do solo em estudo.

Tabela 5.1 Granulometria do Solo

\begin{tabular}{ccc}
\hline Granulometria & Com defloculante & Sem defloculante \\
\hline Argila $(<0,005 \mathrm{~mm})$ & 39,4 & 0,4
\end{tabular}




$\begin{array}{ccc}\text { Site }(0,05-0,005 \mathrm{~mm}) & 19,8 & 13,4 \\ \text { Areia }(2,0-0,05 \mathrm{~mm}) & 39,7 & 85 \\ \text { Pedregulho }(>2,0 & 1,2 & 1,2 \\ \mathrm{~mm}) & & \end{array}$

É possível perceber através dos dados expostos em gráfico e tabela que por se tratar de um solo argiloso é necessário o uso de defloculante para que as partículas se desagreguem e assim posso ser obtido a real composição do solo em estudo a partir da sedimentação.

\subsubsection{Massa específica dos Grãos}

A massa específica real dos grãos foi obtida a partir da norma NBR 6508 e foi aferida com um valor de 2,71 .

\subsubsection{Metodologia MCT expedita}

Segundo essa metodologia utilizada para determinação da composição de solos tropicais o solo foi classificado como uma areia argilosa laterítica (LA'- LG'). Sendo a resistência ao esmagamento como muito alta, pelo fato de ser um solo argioloso. O c' encontrado que está diretamente relacionado com argilosidade do material, sendo aferido como médio.

\subsubsection{Limites de Atteberg}

A tabela 5.2 expõe os dados relativos aos limites de Atteberg encontrados no solo em estudo, sendo eles o limite de liquidez (Figura 5.2), limite de plasticidade e índice de plasticidade. 


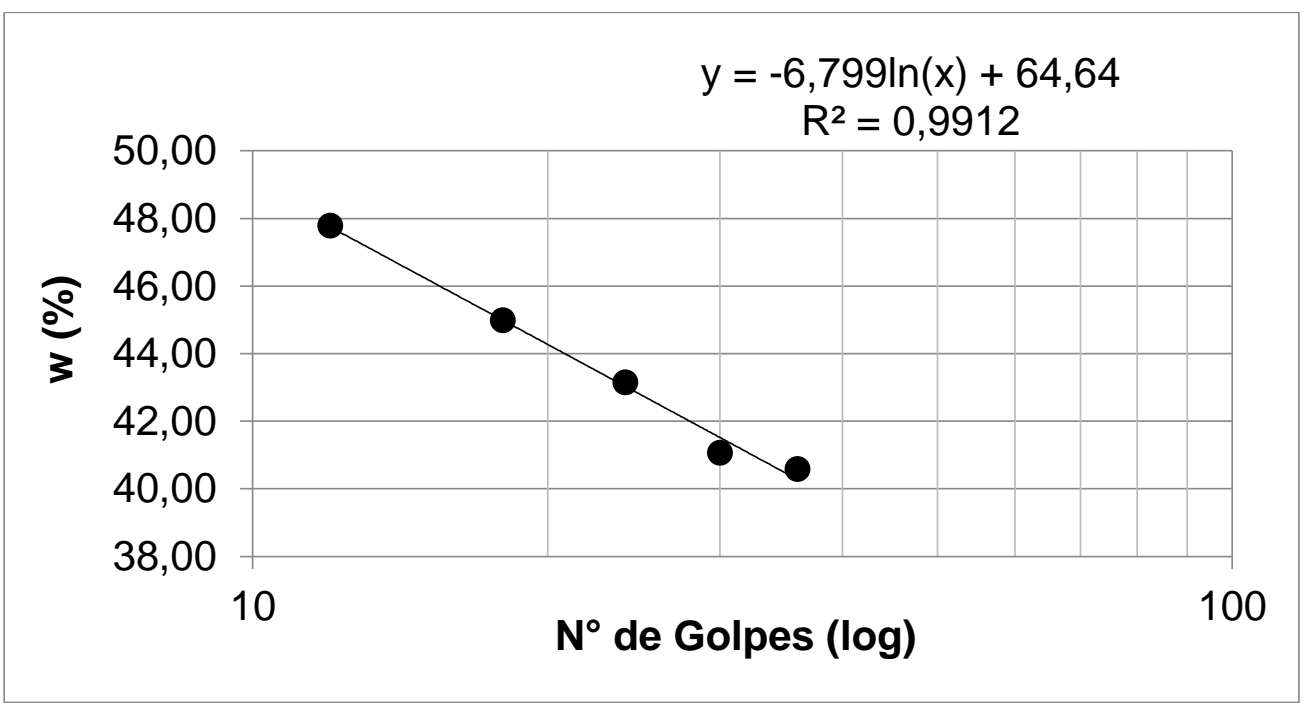

Figura 5.2 Curva de Limite de Liquidez

Assim foi classificado segundo a tabela de classificação de índice de plasticidade (DAS, 2011) como um solo de plasticidade média.

Tabela 5.2 Limites de consistência do solo

\begin{tabular}{ccc}
\hline Propriedades & Unidade & Amostra \\
\hline $\begin{array}{c}\text { Limite de } \\
\text { Liquidez (LL) }\end{array}$ & $\%$ & 43 \\
Limite de & $\%$ & 31 \\
Plasticidade (LP) & & \\
Índice de & $\%$ & 12 \\
Plasticidade (IP) & & \\
\hline
\end{tabular}

\subsection{CARACTERIZAÇÃO DAS FIBRAS}

\subsubsection{Fibra Cerâmica}


A fibra cerâmica, através das condições em que foram doadas, foi necessário fazer um peneiramento na peneira de $\mathrm{n}^{\circ} \mathbf{4 0}$ e trabalhar com o material passante na peneira no 60 com abertura de $0,25 \mathrm{~mm}$.

Sua massa específica determinada através do pentapicnômetro foi aferida em 2,54.

\subsubsection{Fibra PROMEX}

A fibra PROMEX foi moída e passada na peneira 1,2 mm com diâmetro variando entre 0,2 e $3 \mathrm{~mm}$.

Sua massa específica determinada com o pentapicnômetro foi de 1,35.

\subsection{COMPACTAÇÃO}

\subsubsection{Compactação Proctor}

Para se obter os parâmetros ótimos do solo, foi feita a compactação segundo a norma NBR 6457 e 7182 para estabelecer qual é a umidade ótima e o peso específico máximo para as três energias adotadas nesta pesquisa : Normal, Intermediária e Modificada.

Como um comportamento natural de um solo caracteristicamente argiloso, a tendência da curva conforme a energia de compactação solicitada foi a de seu peso específico aumentar ao passo que sua umidade ótima diminui, como estabelecido na figura 5.3. Segundo (DAS, 2011) esse comportamento da curva de compactação é considerado como formato sino, por ter um limite de liquidez entre 30 e 70. 


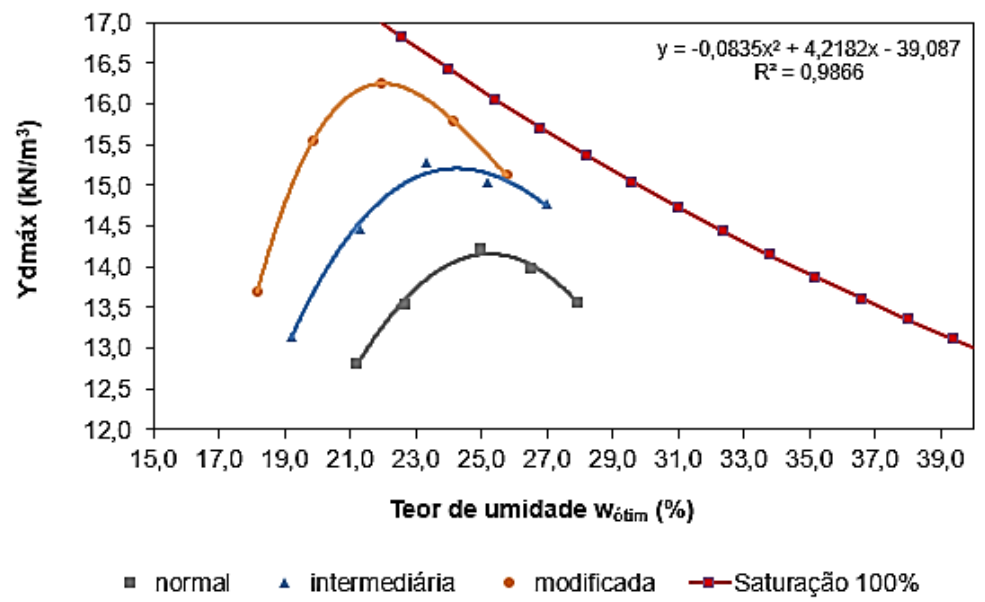

Figura 5.3 Curvas de compactação

$\mathrm{Na}$ tabela 5.3 são estabelecidas as umidades ótimas (w\%) encontradas para cada energia de compactação adotada e o peso específico seco máximo (yd máx).

Tabela 5.3 Umidade ótima e peso específico máximo para cada energia de compactação

\begin{tabular}{ccc}
\hline $\begin{array}{c}\text { Energia de } \\
\text { compactação }\end{array}$ & Wótima (\%) & $\begin{array}{c}\text { yd máx } \\
\left(\mathrm{KN} / \mathrm{m}^{3}\right)\end{array}$ \\
\hline Normal & 25,2 & 14,25 \\
Intermediária & 22,7 & 15,3 \\
Modificada & 22 & 16,25 \\
\hline
\end{tabular}

\subsubsection{Compactação em miniatura}

Para aferir a resistência à compressão do solo em estudo em sua condição ótima, estabelecida através da compactação Proctor, os corpos de prova foram compactados no cilindro em miniatura em cinco camadas. Resultando em CPs com $50 \mathrm{~mm}$ de diâmetro e uma altura de $100 \mathrm{~mm}$, sendo controlada a quantidade de golpes e carga utilizada em cada camada de solo. 
Diante das dificuldades impostas pela prensa estática utilizada, os corpos de prova obtiveram algumas variações de altura em cerca de $5 \%$ do ideal, ficando desnivelados, sendo necessário retifica-los manualmente.

Já os corpos de prova para ensaios de resistência a tração foram compactados em uma única camada com $20 \mathrm{~mm}$ de altura e não obtiveram variações consideráveis na altura final obtida.

\subsection{ENSAIO DE RESISTÊNCIA MECÂNICA À COMPRESSÃO E A TRAÇÃO}

Empregando as metodologias dispostas para ensaio nas normas NBR 12770 e DNER -ME foram verificadas a resistência à compressão e a tração respectivamente.

Os resultados referentes a resistência à compressão simples do solo com e sem reforço dispostos na figura 5.4, em parâmetros gerais obteve resultados semelhantes , mas com a adição de fibra cerâmica houve um leve acréscimo de resistência, devido a sua composição físico-química proporcionar uma boa adaptação ao solo em estudo, mas ao se romperem gerou poucas fissuras com alta expansão (figura 5.5 b). Já a fibra PROMEX apesar da resistência ao rompimento ser próximo ao solo natural, a propagação das fissuras foi muito dissipativa (figura 5.5 a ), e o solo conseguiu resistir mais após a fissuração como pode ser comparado nas figuras 5.6, 5.7, 5,8.

Evidenciando que, foi possível perceber alguns erros ao tentar se aproximar da altura estipulada para os corpos de prova, assim ocasionando uma compactação de mais de 100\% gerando assim uma leve alteração no peso específico do material, além de que observou-se uma tendência natural em todos os corpos de prova a gerar trincas onde estavam as junções do cilindro, composto por três peças como pode ser visto na figura 4.15 (a) . E ainda a fibra cerâmica apresentou um peso específico mais elevado devido ao fato de ser mais densa que o outro compósito adotado. 


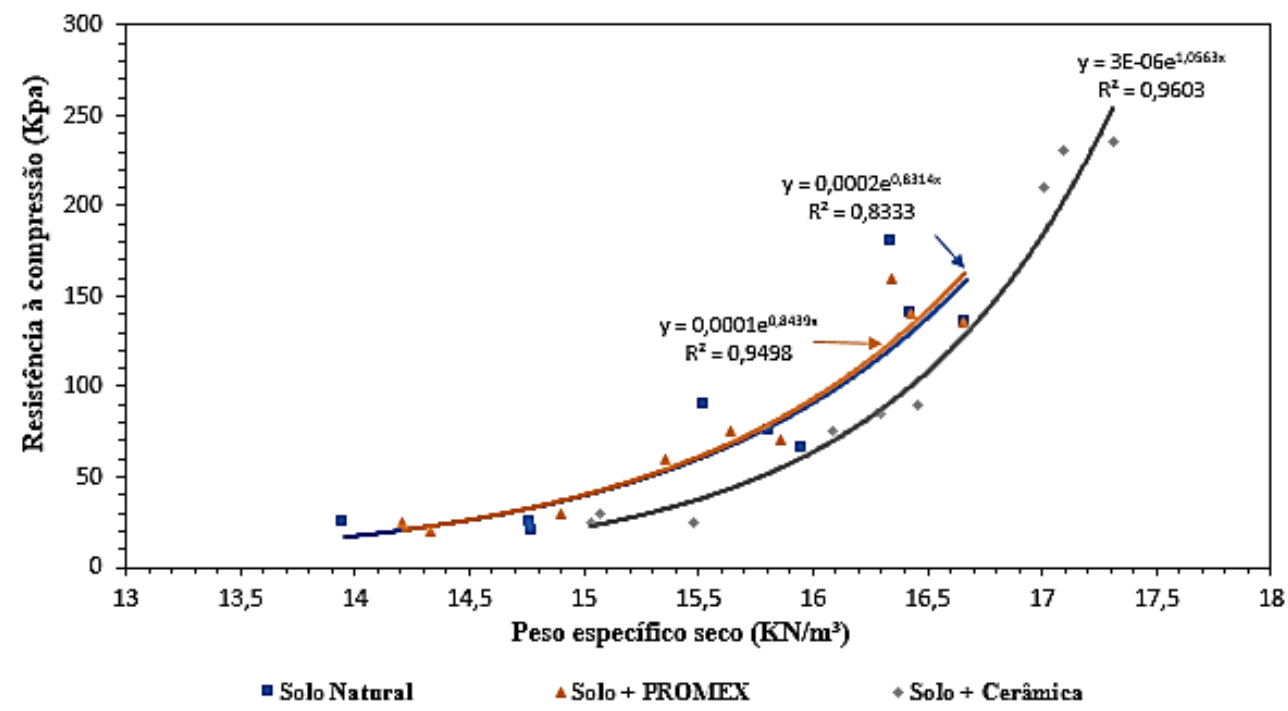

Figura 5.4 Curvas de Resistência à Compressão Simples

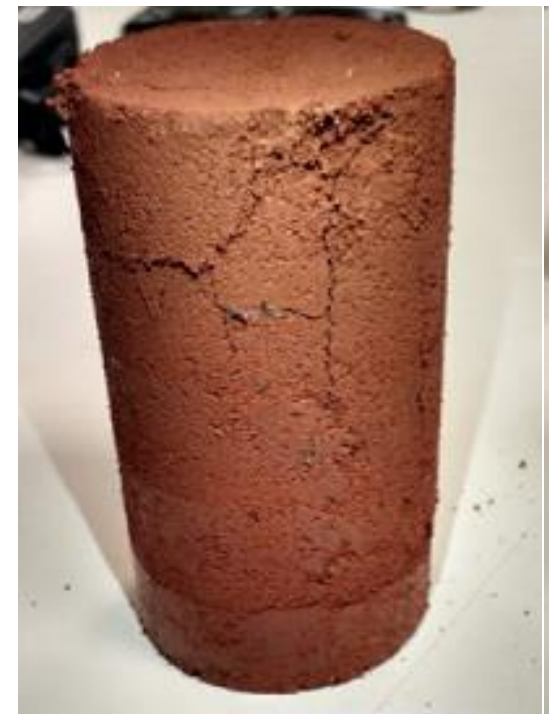

(a)

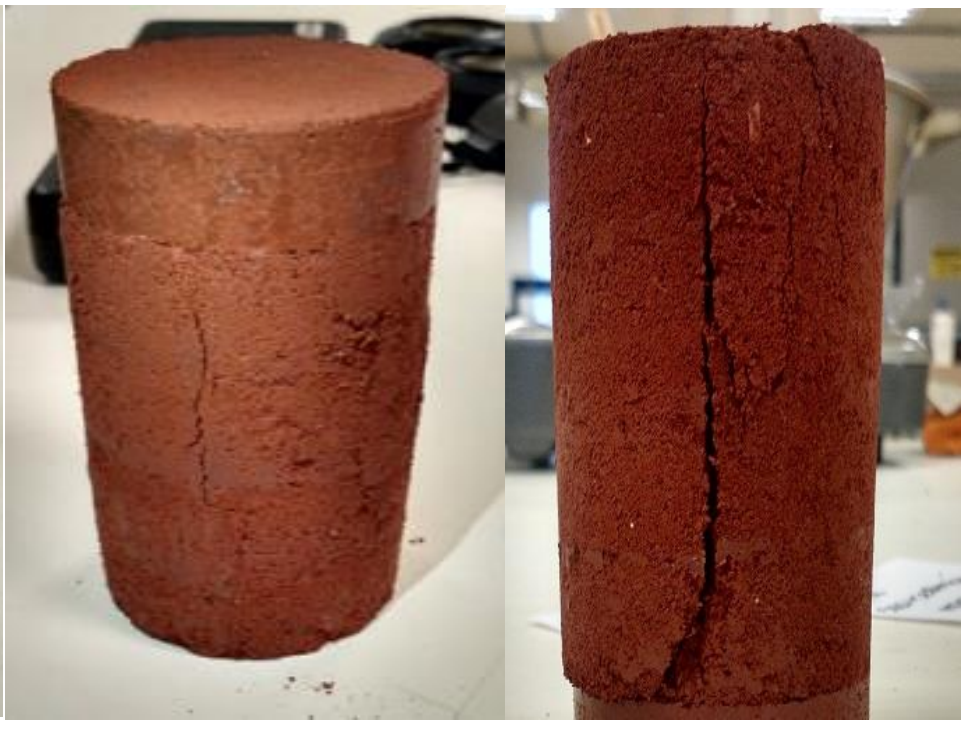

(b)

(c)

Figura 5.5 Fissuras no solo : (a) Solo Natural (b)Solo com Fibra PROMEX (c) Solo com Fibra cerâmica 


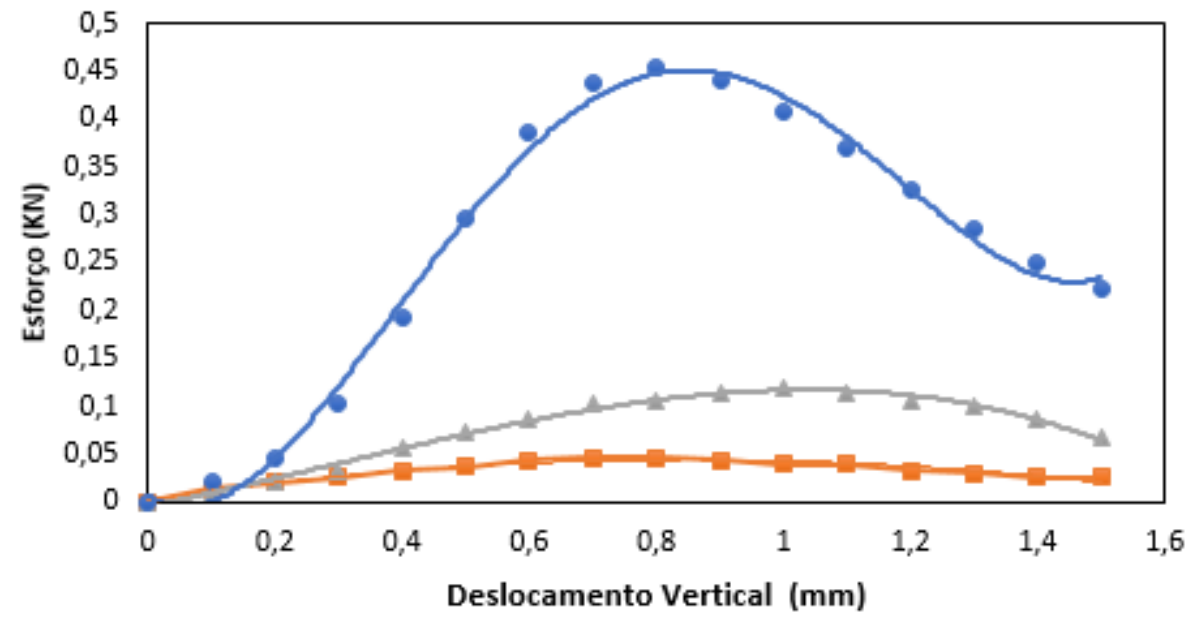

- -Energia Normal $\quad$ E Energia Intermediária - Energia Modificada

Figura 5.6 Deformação do Solo Natural

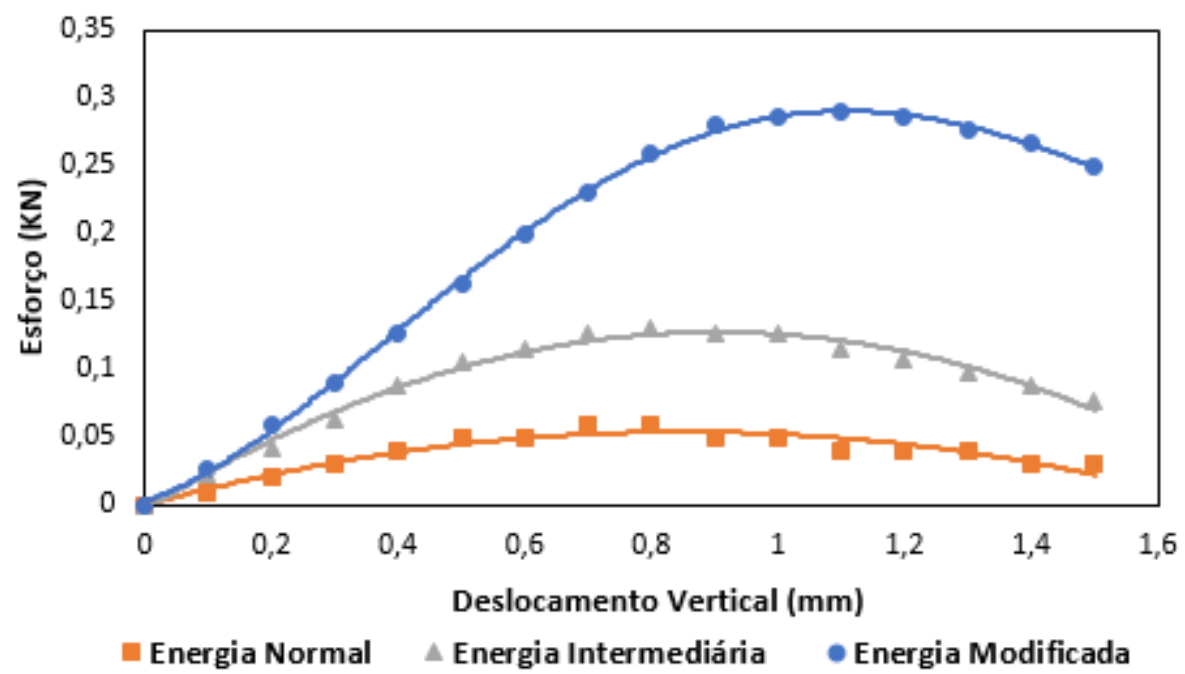

Figura 5.7 Deformação do Solo + Fibra PROMEX 


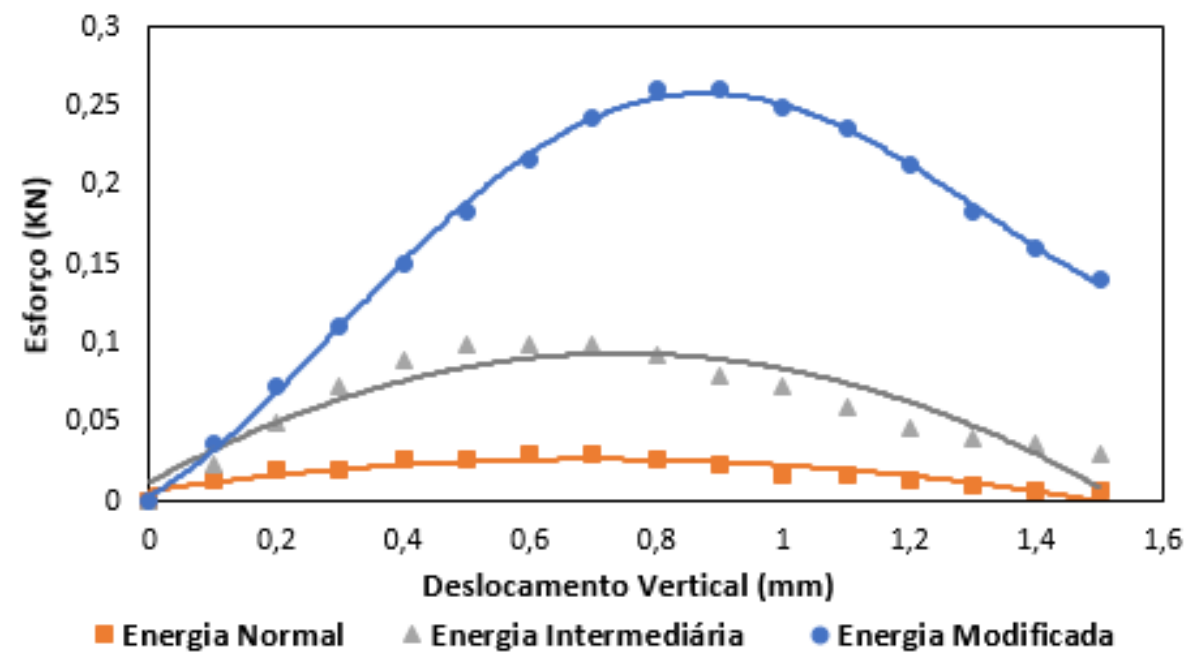

Figura 5.8 Deformação do Solo + Fibra Cerâmica

Para os ensaios de resistência a tração com e sem reforço, das amostras de solo preparadas com diâmetro de $50 \mathrm{~mm}$ e altura de $20 \mathrm{~mm}$, compactados em uma única camada, foi observado segundo a figura 5.9 que o solo natural apresentou uma resistência de pico próximo a do solo reforçado com fibra cerâmica, mas ao se romperem rapidamente se desintegrava, para todas as energias aplicadas ,como é vista a deformação unitária nas figuras 5.10 e 5.12. O fato da fibra cerâmica apresentar uma resistência maior está ligada a boa adaptação do material ao solo, mas o seu rompimento integral acontecia rapidamento (figura 5.13 c). Já para a inclusão de fibra PROMEX foi possível perceber um aumento da resistência a baixas cargas aplicadas, mas uma resistência final menor, fato diretamente relacionado com os filamentos das fibras que fizeram com que o solo suportasse uma maior carga e após sua fissuração como é explicado por (SALES,2011) as trincas demoraram a se espalhar pelo solo como mostra na figura 5.11. e assim o solo demorou a se desintegrar por completo (figura 5.13 b) 


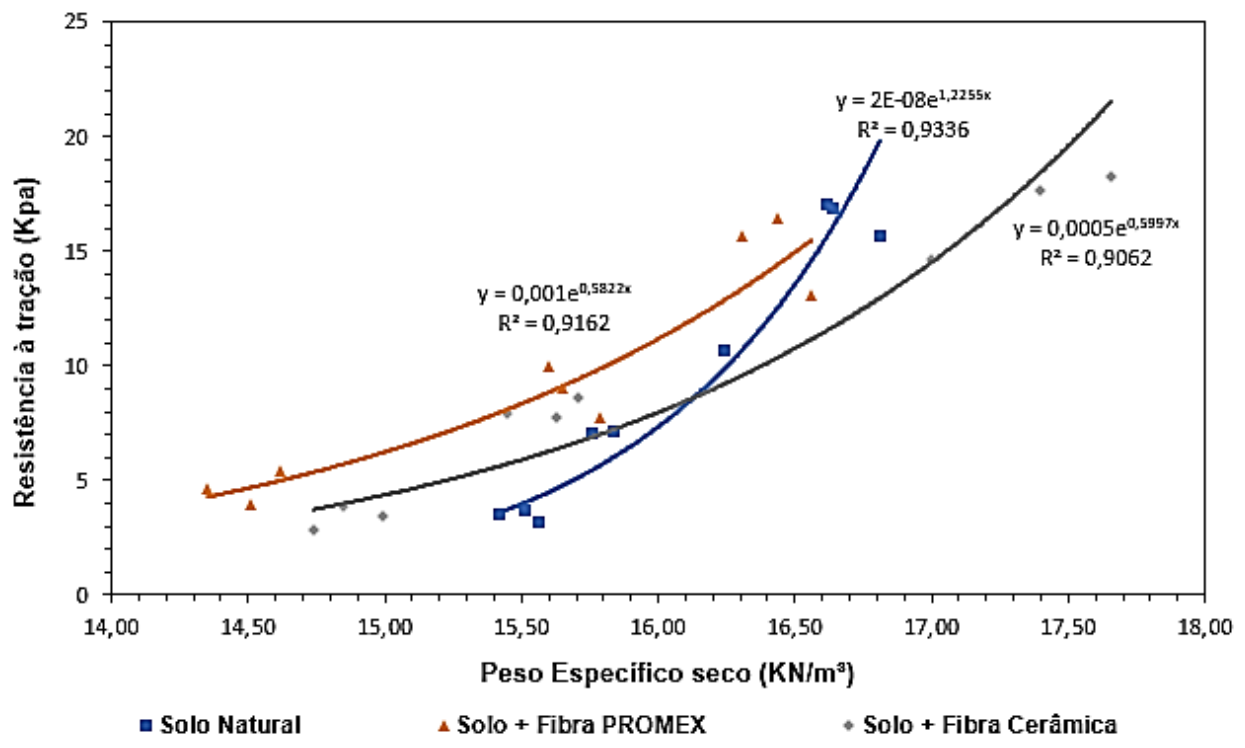

Figura 5.9 Curvas de Resistência à Tração

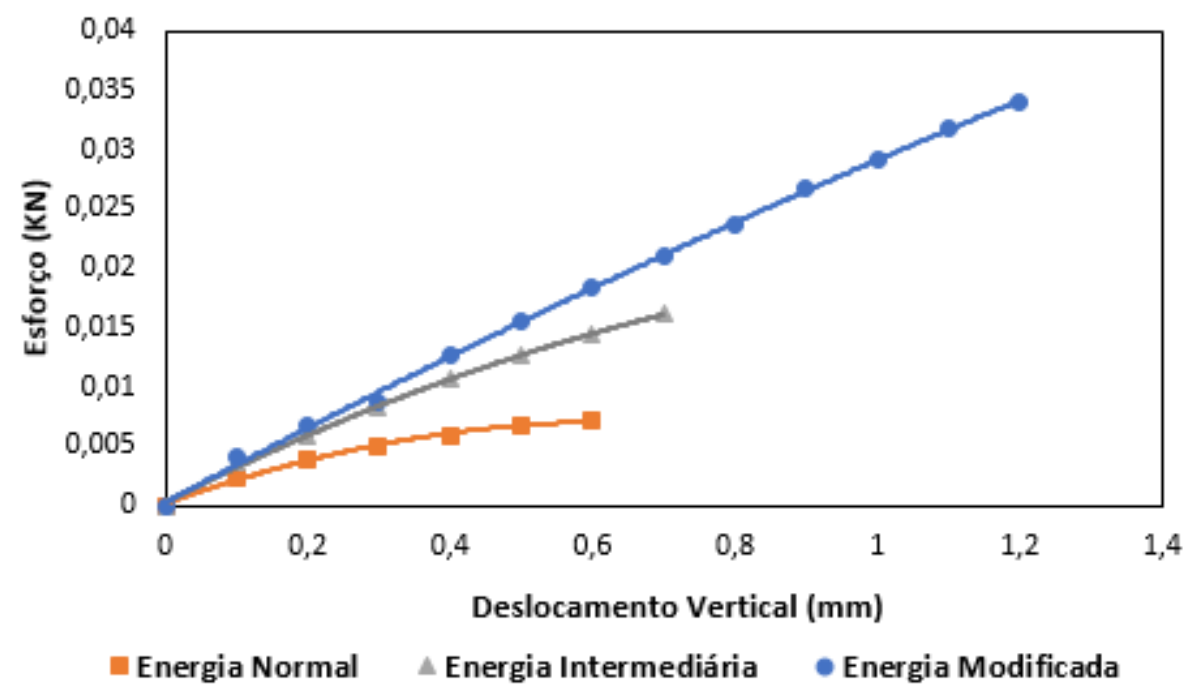

Figura 5.10 Deformação do Solo Natural para esforço de tração 


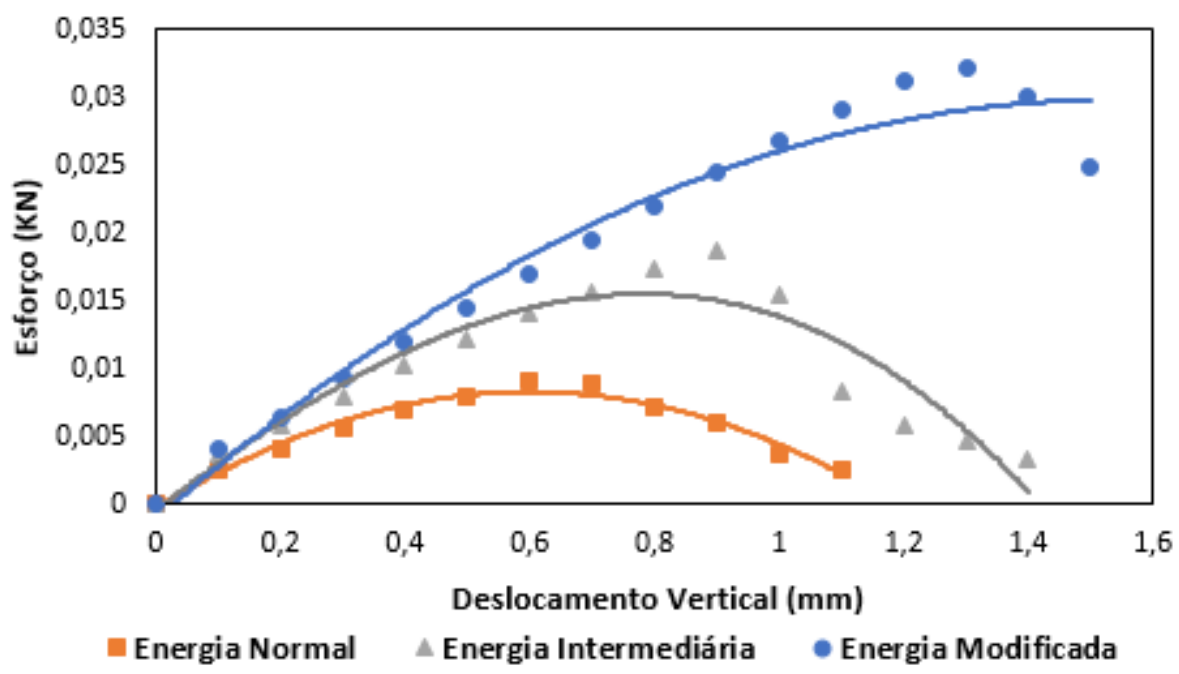

Figura 5.11 Deformação do Solo + Fibra PROMEX para esforço de tração

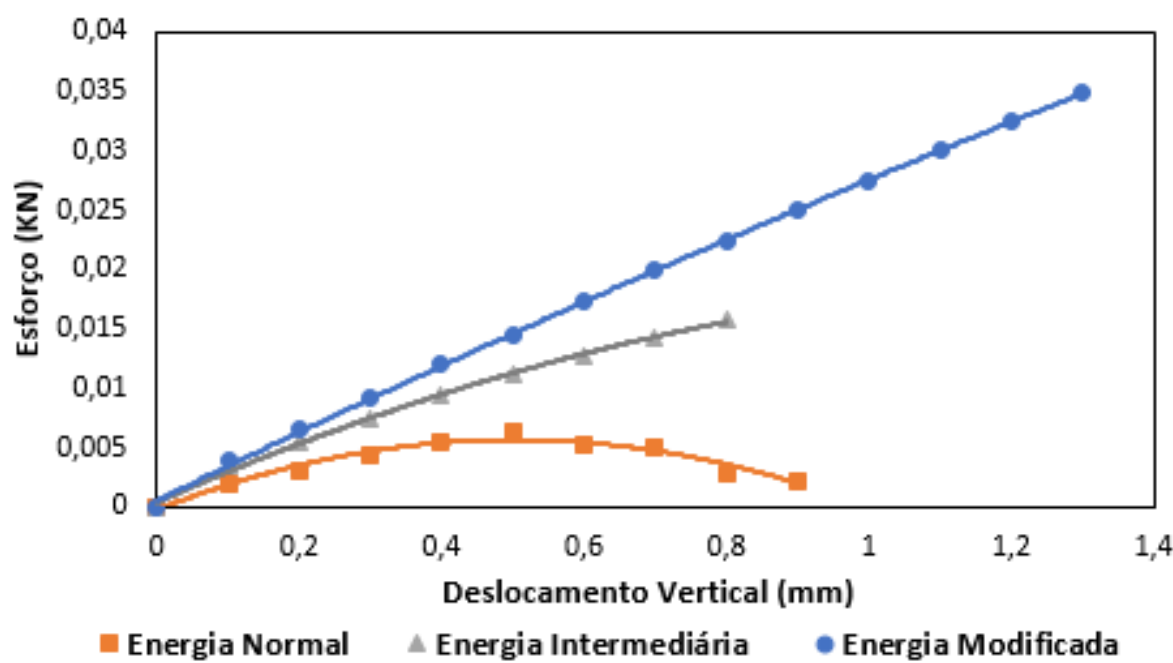

Figura 5.12 Deformação do Solo + Fibra Cerâmica para esforço de tração

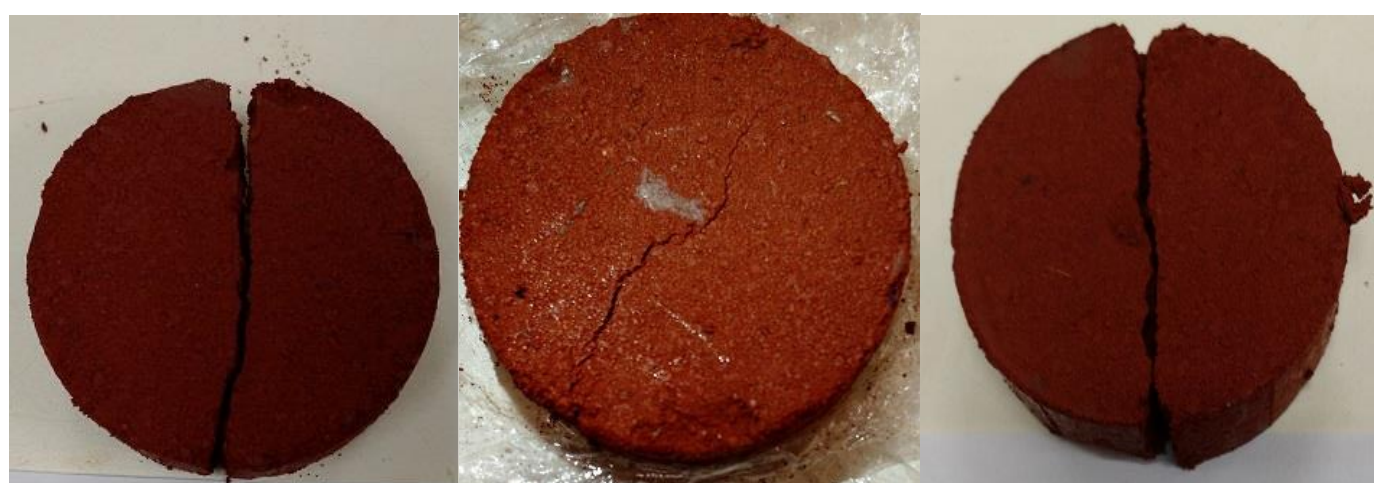

(a)

(b)

(c) 
Figura 5.13Fissuras nos corpos de prova submetidos a tração : (a) Solo Natural (b)Solo com Fibra PROMEX (c) Solo com Fibra Cerâmica

\subsection{ENSAIO DE RESISTÊNCIA MECÂNICA AO CISALHAMENTO DIRETO}

Os resultados obtidos para o cisalhamento direto do solo com e sem adição de reforço de forma saturada, foram realizados segundo a norma ASTM D 3080.

Para a energia normal de compactação foram utilizadas as cargas de 100, 200 , 300 e $400 \mathrm{kPa}$, e os resultados são apresentados na figura 5.14, 5.15 e 5.16 .

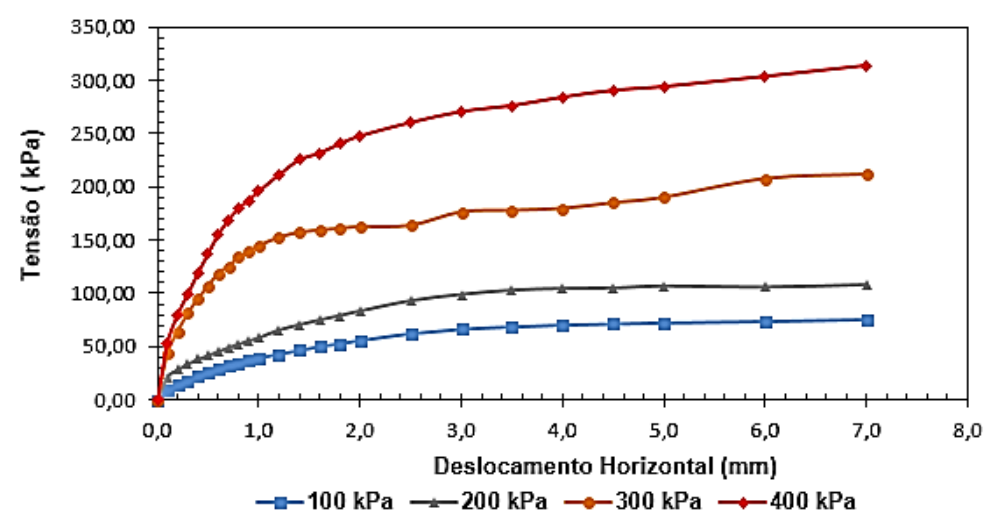

Figura 5.14 Curvas de cisalhamento para o solo natural

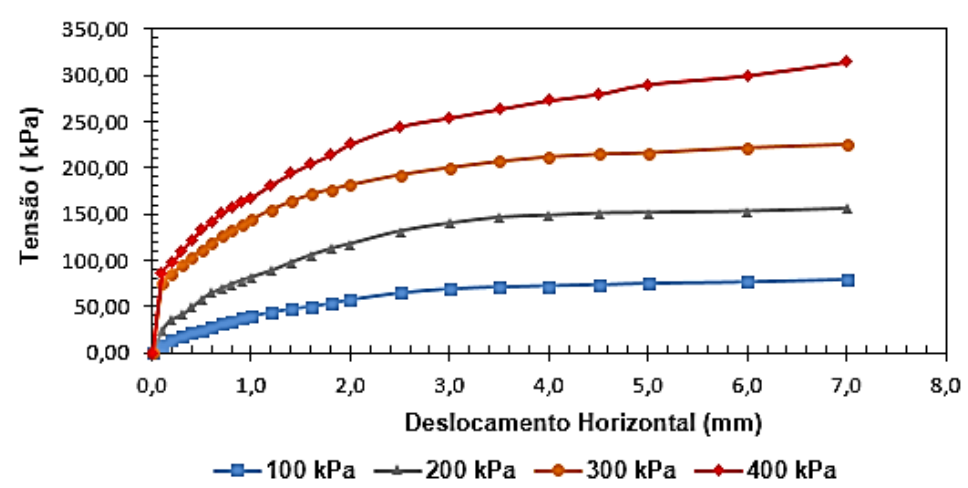

Figura 5.15 Curvas de cisalhamento para o solo + Fibra PROMEX 


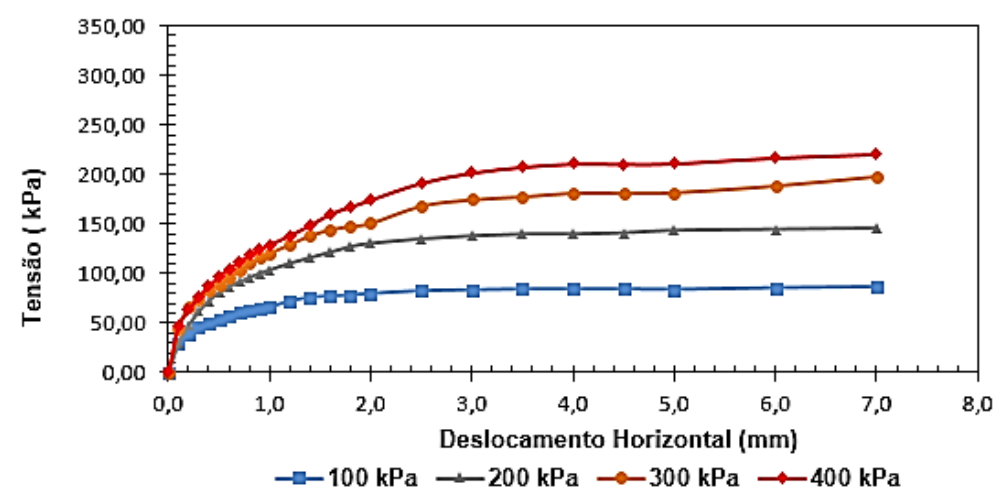

Figura 5.16 Curvas de cisalhamento para o solo + Fibra Cerâmica

Pode se perceber de forma comparativa com solo natural, que através da inclusão de fibra PROMEX o solo apresentou um aumento da sua resistência ao cisalhamento devido ao fato das fibras em pequenos filamentos fazem com que o solo resista a tensão cisalhante imposta e também tenha as curvas melhor distribuídas, com uma tensão cisalhante bem equilibrada ao longo da curva, como explica ( TRINDADE 2006) e (CASAGRANDE, 2005) relatando uma estabilidade maior nas curvas de solo reforçado, onde obtiveram uma menor queda pós pico.

A fibra cerâmica diminui a resistência do solo ao cisalhamento fato atribuído a sua condição de inserção ao solo na forma de pó, o que faz com que sua adição para resistência a tensão cisalhante não seja considerada.

Para a energia intermediária de compactação foi observada os mesmos critérios estabelecidos no cisalhamento para a energia normal, onde a fibra cerâmica apresentou baixa resistência e a fibra PROMEX acrescentou, com o aumentou da coesão e do ângulo de atrito expostos nas figuras 5.17, 5.18 e 5.19. 


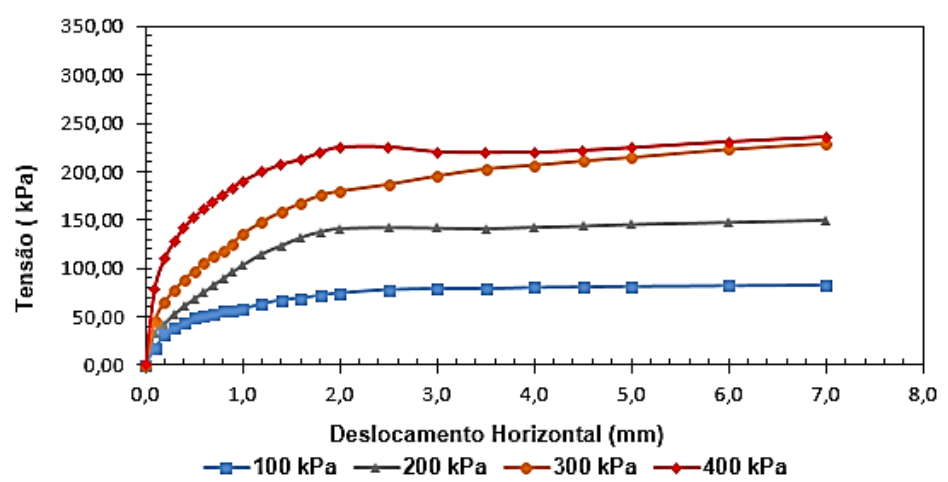

Figura 5.17 Curvas de cisalhamento para o solo natural

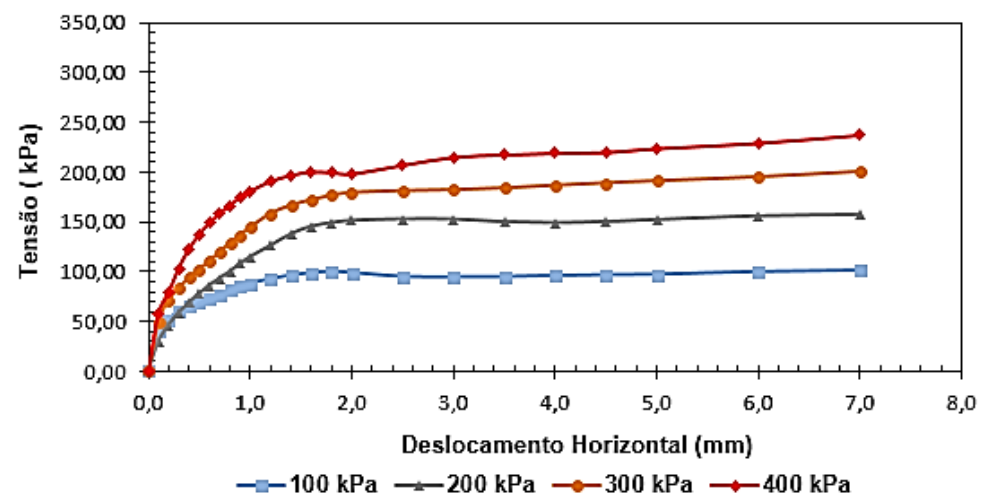

Figura 5.18 Curvas de cisalhamento para o solo + Fibra PROMEX

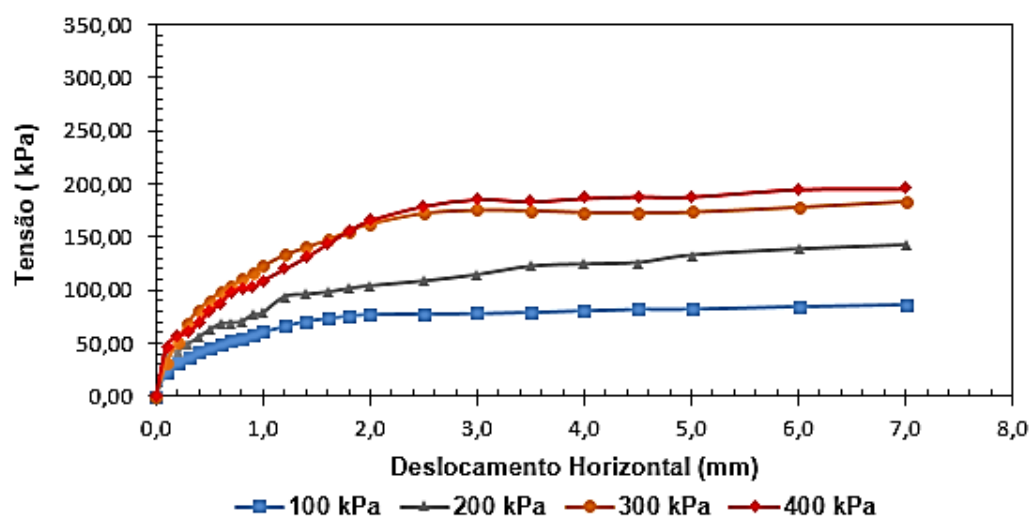

Figura 5.19 Curvas de cisalhamento para o solo + Fibra Cerâmica

Através da envoltória de ruptura para as energias normal e intermediária (figura 5.20 e 5.21) e (tabelas 5.8 e 5.9) pode-se confirmar a baixa resistência do solo adicionado com fibra cerâmica, pois foi a envoltória com a menor coesão e ângulo de atrito 
mensurado. Já a fibra PROMEX aumentou a coesão do solo e seu ângulo de atrito permaneceu próximo ao valor do solo natural como também explica (LEOCÁDIO ,2005) apresentando em sua pesquisa um aumento da coesão com a adição de fibras e permanecendo próximos os valores de ângulo de atrito. Assim inclusão de fibra PROMEX apresentou uma melhora na sua resistência a tensão cisalhante exercida, devido ao fato dos filamentos das fibras potencializarem a resistência do solo.

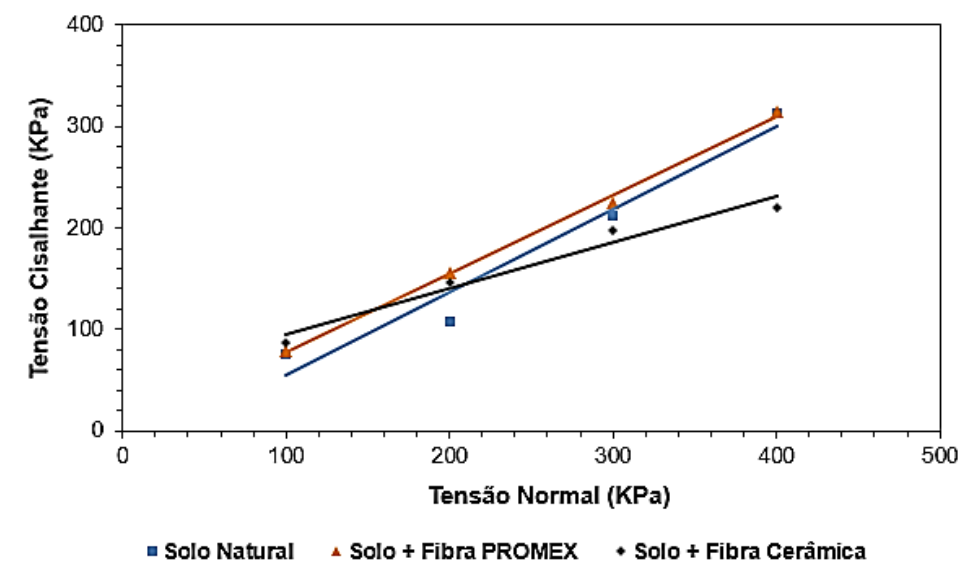

Figura 5.20 Envolvente de Ruptura (Energia Normal)

Tabela 5.4 Coesão e Ângulo de atrito para energia normal

\begin{tabular}{lccc}
\hline Energia & Solo & Solo + & Solo + \\
Notural & $\begin{array}{c}\text { Fibra } \\
\text { Têxtil }\end{array}$ & $\begin{array}{c}\text { Fibra } \\
\text { Cerâmica }\end{array}$ \\
\hline Coesão & 27 & 60 & 42 \\
Ângulo de & $39^{\circ}$ & $38^{\circ}$ & $24^{\circ}$ \\
Atrito & & & \\
\hline
\end{tabular}




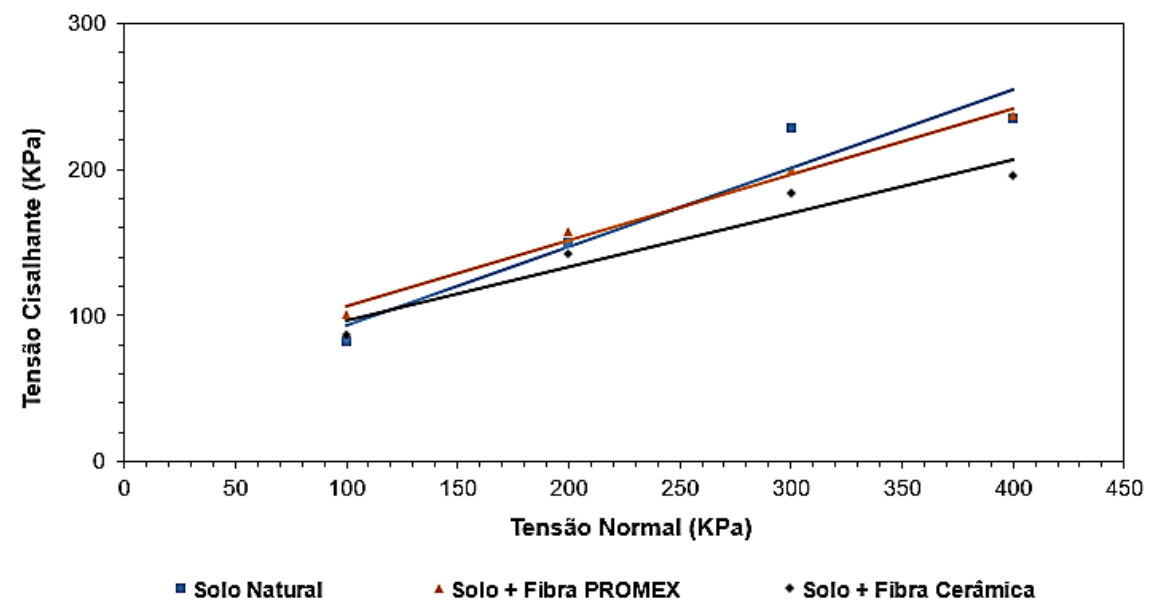

Figura 5.21 Envolvente de Ruptura (Energia Intermediária)

Tabela 5.5 Coesão e Ângulo de atrito para energia intermediária

\begin{tabular}{cccc}
\hline $\begin{array}{c}\text { Energia } \\
\text { Intermediária }\end{array}$ & $\begin{array}{c}\text { Solo } \\
\text { Natural }\end{array}$ & $\begin{array}{c}\text { Solo }+ \\
\text { Fibra } \\
\text { Têxtil }\end{array}$ & $\begin{array}{c}\text { Solo + } \\
\text { Fibra } \\
\text { Cerâmica }\end{array}$ \\
\hline Coesão & 40,1 & 61,1 & 60 \\
Ângulo de & $28^{\circ}$ & $24^{\circ}$ & $20^{\circ}$ \\
Atrito & & & \\
\hline
\end{tabular}

\section{CONSIDERAÇÕES FINAIS}

Através dos resultados obtidos na presente pesquisa é possível concluir que:

- Ao adicionar fibra cerâmica em pó ao solo foi observado que houve uma melhora na sua resistência a compressão e a tração, mas ao se romperem suas fissuras eram facilmente espalhadas pela matriz com grande expansão, comparando com o outro material adotado. Ao cisalhamento direto não obteve resultados satisfatórios.

- Para a fibra PROMEX em filamentos, notou-se que a sua inclusão não alterou significativamente sua resistência a compressão e a tração, mas após o início das fissuras no solo ela fez com que o compósito suportasse uma carga por mais tempo que as demais condições investigadas, apresentando também uma leve melhora na 
resistência ao cisalhamento devido a sua composição filamentar aumentar o ângulo de atrito e a coesão do solo.

- Assim considera -se viável a inclusão de fibras recicladas para aumentar a resistência do solo, por se tratar de um material de baixo custo e sendo sustentável contribui para um bom reaproveitamento de resíduos.

- Para pesquisas futuras é indicado moldar um cilindro em uma única peça, para que ao romper os corpos de prova, eles não tenham a tendência de se romperem nas juntas. É necessário também aprofundar os estudos com o uso dessas fibras recicladas variando sua porcentagem e também misturando as duas fibras em uma mesma matriz para verificar seu comportamento.

\section{REFERÊNCIA BIBLIOGRÁFICA}

ABNT - Associação Brasileira de Normas Técnicas

_NBR 7181: Solo - Análise granulométrica. Rio de Janeiro, 1984

_NBR 6459: Solo - Determinação do limite de liquidez. Rio de Janeiro, 1984.

_NBR 7180: Solo - Determinação do limite de plasticidade. Rio de Janeiro, 1988.

_NBR 7182: Solo - Ensaio de compactação. Rio de Janeiro, 1986.

_NBR 12770: Solo coesivo - Determinação da resistência à compressão não confinada - Método de ensaio. Rio de Janeiro, 1992.

_NBR 10838: Solo - Determinação da massa específica aparente de amostras indeformadas, com emprego de balança hidrostática.

ASTM - American Society for testing materials

_ ASTM D 3080-98. Standard test method for direct shear test of soil under
consolidated drained condition.

DNER - Departamento Nacional de Estradas de Rodagem 
_DNER-ME 181/94 : Solos estabilizados com cinza volante e cal hidratada determinação da resistência à tração por compressão diametral.

_DNER-ME 228/94: Solos - compactação em equipamento miniatura.

BOTELHO, Edson C.; REZENDE, Mirabel C.. Caracterização Mecânica de Compósitos de Poliamida/Fibra de Carbono Via Ensaio de Cisalhamento Interlaminar e de Mecânica da Fratura. Polímeros: Ciência e Tecnologia, São José dos Campos, v. 12, n. 3, p.153-163, jul. 2002.

CASAGRANDE, M.d.T. (2005). Comportamento de Solos Reforçados com Fibras Submetidos a Grandes Deformações. Tese de Doutorado, Universidade Federal do Rio Grande do Sul, Porto Alegre, RS, 219 p.

CUNHA, Adriano Ferreira da et al. Caracterização, beneficiamento e reciclagem de carepas geradas em processos siderúrgicos. Escola de Minas, Ouro Preto, v. 59, n. 1, fev. 2006.

DAS, B. M. Fundamentos de Engenharia Geotécnica. 7. ed. São Paulo: Cengage Learning.

DIAS, M. V. P.(2013). Utilização de Fibras de Polipropileno na Melhoria do Comportamento de Solos Coesivos. Dissertação de Mestrado, Universidade de Trásdos-montes e Alto Douro, Portugal, $124 \mathrm{p}$.

EVANGELISTA, N. (2011).Estudo da utilização de resíduos industriais de lã cerâmica e lã de vidro em argamassa e concreto. Tese de Doutorado, Universidade Federal de Ouro Preto, Ouro Preto, MG, 186 p.

FINKLER, M. et al. (2005) Compósitos de HDPE com resíduos de fibras têxteis.: Parte I: caracterização mecânica. São Carlos, 15 (3).

GHAVAMI, K.; TOLEDO FILHO, R.; BARBOSA, N. (1988). Behavior of composite soil reinforced with natural fibres. Elsevier, p.39-48.

LEOCÁDIO, G. A. S. (2005). Reforço de Solo Laterítico com Fibras de Sisal de Distribuição Aleatória Tratadas Superficialmente com EPS Reciclado. Dissertação de Mestrado. Universidade Federal de Ouro Preto, Ouro Preto, MG, 100 p. 
MUNTOHAR, A. S. et al.(2013). Engineering Properties of Silty Soil Stabilized with Lime and Rice Husk Ash and Reinforced with Waste Plastic Fiber. Journal Of Materials In Civil Engineering. p. 1260-1270.

OLIVEIRA,T.G. et al.(2016). Avaliação do Uso de Fibras de Garrafas PET como Reforço de Solos Compactados. Congresso Brasileiro de Mecânica dos Solos e Engenharia Geotécnica, COBRAMSEG, Belo Horizonte , MG,18.

RESCHETTI JÚNIOR, P. R. (2008). Avaliação do Comportamento Mecânico de um Solo Arenoso Fino Reforçado com Fibras para Uso em Pavimentação. Dissertação de Mestrado, Universidade de São Paulo, São Carlos, SP, 145 p.

SALES, K. C. S. (2011). Melhoria de Solos por Inclusão de Fibras Naturais. Dissertação de Mestrado, Universidade de Brasília , Brasília , DF, 113 p.

SENOL, A. et al. (2012). Improvement of High and Low Plasticity Clayey Soils Using Polypropylene Fibers and Fly Ash. American Society of Civil Engineers ,ASCE, p.500509.

SILVA, C. C. (2007). Comportamento de Solos Siltosos quando Reforçados com Fibras e Melhorados com Aditivos Químicos e Orgânicos. Dissertação de Mestrado, Universidade Federal do Paraná , Curitiba, PR, 170 p.

SOUZA, E. L. (2006). Estudo e desenvolvimento de um processo de tratamento de resíduos siderúrgicos através da técnica de bombardeamento ultra-sônico. Tese de Doutorado, Universidade Federal de Ouro Preto, Ouro Preto, MG, 128 p.

TRINDADE, T. P. et al. (2006). Estudos laboratoriais de Comportamento de um Solo Residual Arenoso Reforçado com Fibras de Polipropileno, Visando à Aplicação em Estradas Florestais. Sociedade de Investigações Florestais, Viçosa, 30 (2): 215-222. 